\title{
Exploring future scenarios of ethanol demand in Brazil and their land-use implications
}

Milton Aurelio Uba de Andrade Juniora,b,*, Hugo Valinc, Aline C Soterronic,d,**, Fernando M Ramosd, Anthony Haloga

a School of Earth and Environmental Sciences, The University of Queensland, Brisbane QLD 4072 Australia

b State Department of Sustainable Economic Development, Rodovia SC 401, 4756

bl. 2, Saco Grande II, Florianópolis, SC CEP 88032-005, Brazil

c Ecosystems Services and Management, International Institute for Applied Systems Analysis, A-2361 Laxenburg, Austria

d National Institute for Space Research, Av. dos Astronautas 1758, Jardim da Granja, São José dos Campos, SP CEP 12227-010, Brazil

*Corresponding author: miltinhouba@gmail.com

**Corresponding author: soterr@iiasa.ac.at, aline.soterroni@inpe.br

Declarations of interest: none.

\section{Abstract}

Ethanol biofuel demand in Brazil is highly dependent on macroeconomic and policy drivers, making it difficult to anticipate future production and associated environmental implications. Here we develop scenarios of ethanol demand in Brazil towards 2030, based on a thorough examination of key influencing drivers, i.e. GDP and population growth, fleet composition, blending policies, fuel prices and energy efficiency. We then estimate their land-use implications using a detailed partial equilibrium model, GLOBIOM-Brazil. We find that ethanol demand is highly sensitive to the drivers considered and could increase between 37.4 and 70.7 billion litres in 2030 depending on the scenario. Such increase is $13 \%$ and $114 \%$ above the 2018 consumption level. This represents an expansion in sugarcane area between 1.2 and 5 million hectares (14\% - 58\% above the land-use in 2018). Compared to the low demand scenario, a high demand for ethanol in 2030 would drive sugarcane expansion mostly into 
pastureland $(72 \%)$ and natural vegetation mosaics (19\%). Our results suggest that future ethanol demand in Brazil should not substantially affect food production nor native forest. This outcome will however depend on the compliance with the sugarcane agro-ecological zoning (AEZ) by the ethanol sector in Brazil, a key assumption of our projections.

Keywords: Policy drivers; Biofuels; Ethanol demand; Land-use change; Sugarcane; Agroecological zoning.

\section{Introduction}

Brazil is the largest producer of sugarcane crops globally (FAO, 2018), which are essentially used as feedstock in the production of sugar and ethanol. Although the production of sugar is mostly driven by external markets, the ethanol produced in Brazil is primarily consumed domestically in the transportation sector. One of the reasons for this high domestic demand for ethanol is the fuel blend mandate, which currently blends $27 \%$ of anhydrous ethanol (in volume) into the gasoline (E27). Another strong factor is the increasing share of flex-fuel vehicles in the Brazilian light-duty vehicles (LDV) fleet. Flex-fuel vehicles have adapted engines able to use not only the default fuel blend (E27), but also the $100 \%$ hydrous ethanol (E100) and any blend in between this range.

Despite having a consolidated ethanol sector in the country, the Brazilian government has announced on its Nationally Determined Contribution (NDC) for the Paris Agreement the intention to further increase biofuels supply and consumption. This increase is targeted at raising the share of sustainable biofuels in the energy mix up to $18 \%$ by 2030 (Brazil, 2016). Accordingly, the Brazilian legal framework has reinforced commitments like the NDC with 
the recently approved National Biofuels Policy (also known as RenovaBio), as specified by the Law 13576/2017 (Brasil, 2017).

Such strong support towards the biofuel industry is likely to result in the increase of future demand for ethanol in Brazil. However, the association of biofuels production to environmental and socio-economic impacts has caught global attention in the last few decades (Searchinger et al., 2008). Because edible crops, such as sugarcane and soybean, are currently the main feedstock used in biofuel production in Brazil, their associated environmental impacts are typically related to large-scale agriculture production. These impacts include biodiversity threats, ecosystem exposure, soil degradation, water withdrawal and contamination, and landuse change (Foley et al., 2005; Koh and Ghazoul, 2008). Land-use change impacts from biofuels production are a major concern in tropical countries (Danielsen et al., 2009). Land conversion driven by biofuels, in addition to affecting food production, could release more carbon dioxide emissions than what biofuels are expected to save in the first place (Smith and Searchinger, 2012). Fargione et al. (2008) has drawn attention to the "biofuel carbon debt" caused by biofuel-driven land-use change. They indicate that it would take 17 years of ethanol replacing fossil fuels to offset a potential carbon debt created by converting Brazilian wooded Cerrado lands into sugarcane crops. Lapola et al. (2010) studied both direct and indirect landuse changes of sugarcane ethanol production in this regard. They show that it would take four years to offset carbon emissions when only direct emissions from land-use change are accounted. However, offsetting carbon emissions from indirect land-use change (e.g. land conversion caused by sugarcane pushing rangelands into the Amazon rainforest and Cerrado) could require 40 more years of fossil fuels replacement. The work from Lapola et al. (2010) was novel and important to understand the dynamics of direct and indirect land-use changes driven by biofuels in a Brazilian context. However, results from their modelling framework were based on Brazil's biofuel production targets that did not materialize. In 2010, the authors 
assumed projections of 50 billion litres of ethanol demand by 2020 - a prediction inconsistent to the consumption of 33 billion litres observed in 2018 (CONAB 2019). A crucial reason for understanding the future ethanol demand is its implications on land-use and competition, since sugarcane is the main feedstock for biofuel production in Brazil. Disentangling the contribution of different drivers of change is indeed a necessary step to navigate the space of possible results obtained in projections and policy assessment using land-use change modelling (Verstegen et al. 2016).

One explanation for the disparity between ethanol demand projections used by Lapola and colleagues in 2010 and the actual ethanol consumption observed lately could be the uncertainty around some factors influencing ethanol consumption in Brazil. From a macroeconomic perspective, GDP per capita (Figure 1a) influences passenger transport demand with direct consequences in fuel consumption. On the other hand, regulatory programs also play an important role by altering fuel blend mandates (Figure 1b). Relative prices between ethanol and the default fuel blend (Figure 1c) and the size and composition of the national LDV fleet (Figure 1d) likewise influence ethanol consumption. Regulation affects these factors by applying subsidies and fuel price stabilisation measures, or having governmental programs influencing the way in which size and composition of the LDV fleet evolves over time.
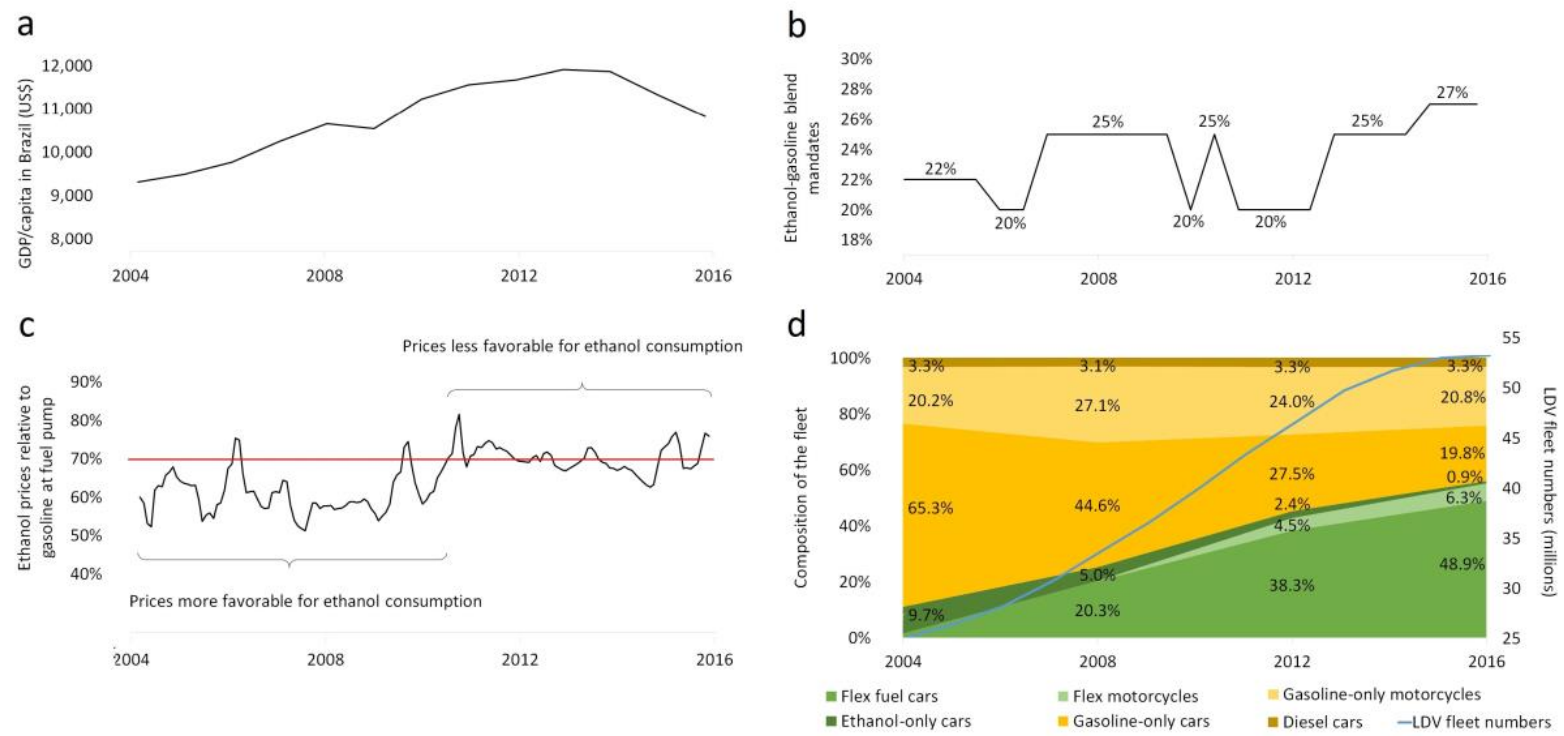
Figure 1. Factors influencing ethanol demand in Brazil. (a) GDP per capita in Brazil, in 2010 US dollars (World Bank, 2017). (b) Fuel blend mandates over the years in Brazil. (c) Relative prices between ethanol and the default fuel blend (ANP, 2017a). (d) Light-duty vehicle fleet composition and numbers. Data reconstructed based on MMA (2013), CETESB (2017), Sindipeças and Abipeças (2017). See Supporting Information (SI) Table S1 and Table S2.

Here we analyse in detail how macroeconomic and policy drivers can shape the future demand for ethanol in Brazil. We design three different scenarios of ethanol demand towards 2030 to estimate their land-use implications. We first project future demand for passenger transport in Brazil, and combine these projections with other variables (e.g. fuel prices and fuel blend mandates) to predict future demand for fuel. We then model land-use competition using the detailed partial equilibrium economic model GLOBIOM-Brazil (Soterroni et al. 2018). We consider the current land-use policy in Brazil and assume a scenario of imperfect illegal deforestation control in the Amazon and the Cerrado biomes. Our land-use and competition results are key information to understand the consequences of increasing the supply of Brazilian ethanol towards 2030 in the context of the Paris Agreement.

2. Methods and data

We base our methods on three main steps: (1) projection of the light-duty vehicles (LDV) demand for transport towards 2030; (2) estimation of the future fuel consumption associated to the transportation demand; and (3) modelling of the land-use implications of the ethanol demand development. The flow diagram in Figure 2 summarizes the steps of the methods indicating the data, tools and influencing drivers taken into consideration. 


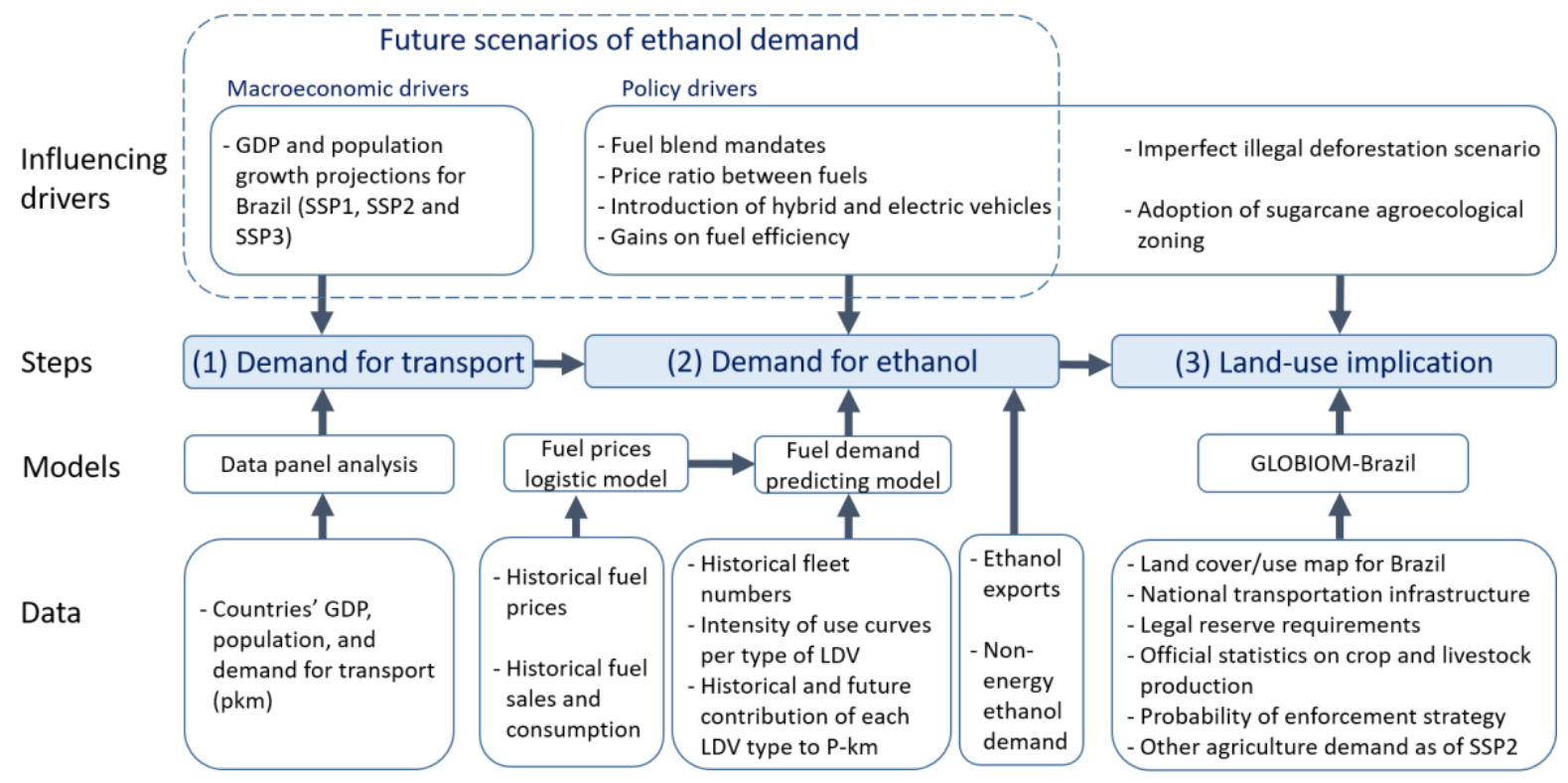

Figure 2. Three main steps of our methods, their models and input data. On top, both macroeconomic and policy drivers. The dashed line highlights the ones considered to vary across future scenarios of ethanol demand.

\subsection{Demand for transport}

We project demand for transport by estimating future passenger-kilometre (pkm) 1 for LDV in Brazil towards 2030. For this purpose, we assess the relationship between road passenger transport by passenger cars, expressed in pkm per capita (y-axis, Figure 3), and GDP per capita (x-axis, Figure 3). We assess this relationship through a panel analysis between 1970 and 2016 on a selection of countries for which transportation data are available. Figure 3 shows this relationship through time, from which we use the resulting function to project future demand for road passenger transport in Brazil. GDP coefficient, intercept and most country fixed effects were found significant2, showing a virtually zero $p$-value. We use transport demand data from OECD statistics (OECD 2018), from which only two countries, Lithuania and

1 A passenger- kilometer (pkm) represents the transport of one passenger over one kilometer.

2 We found significant fixed effects in 20 out of 24 countries in the panel analysis. In the case of Brazil, the fixed effect could not be statistically significant because we only had one single data point added to the regression to derive an estimate of the fixed effect. 
Russian Federation, were removed due to inconsistency in their time series. Brazilian passenger transport demand for LDV in 2013 (5,259 pkm per capita) was added to derive the country fixed effect (COPPE/EPE, 2014). The demand for transport per capita $y$ can be expressed as a $\log -\log$ function of the GDP per capita $x$, according to the relation:

$$
\log \left(y_{i t}\right)=a_{i}+b \log \left(x_{i t}\right)+\mathrm{c}+e_{i t}
$$

where $i$ and $t$ are the indices for country and time; $a$ is the county fixed effect; $b$ is the coefficient applied to the independent variable $x$ and $e$ is the error term $\left(\mathrm{R}_{2}=0.98\right)$. More information on the model is found on Supporting Information (SI) Table S3.

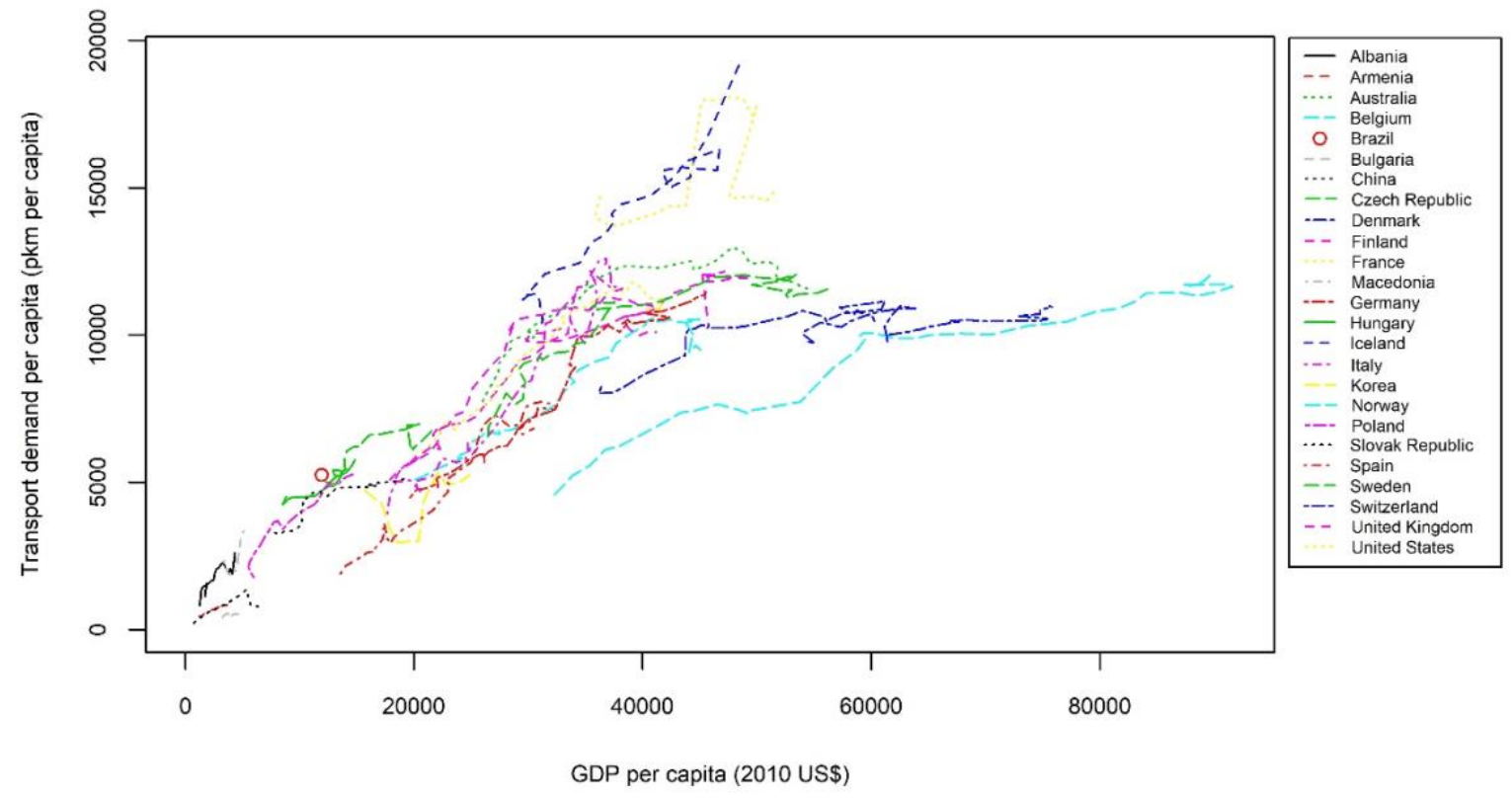

Figure 3. Countries' transport demand per capita and their GDP per capita. Lithuania and Russian Federation were removed due to inconsistency in their time series. Source: Elaborated by the authors using inland road passenger transport data from OECD (2018) and COPPE/EPE (2014). GDP data from World Bank (2017). 
Future values of GDP per capita for Brazil used for transport demand projections (Table 1) are based on GDP and population growth projections for Brazil (Dellink et al., 2017) from the Shared Socioeconomic Pathways (SSP)3.

Table 1. Future macroeconomic drivers for Brazil.

\begin{tabular}{lllllll} 
& \multicolumn{2}{c}{ SSP1 } & \multicolumn{2}{c}{ SSP2 } & \multicolumn{2}{c}{ SSP3 } \\
& $\begin{array}{c}\text { GDP/capita, } \\
\text { 2010 US\$ }\end{array}$ & $\begin{array}{c}\text { Population } \\
\text { (millions) }\end{array}$ & $\begin{array}{c}\text { GDP/capita, } \\
\text { 2010 US\$ }\end{array}$ & $\begin{array}{c}\text { Population } \\
\text { (millions) }\end{array}$ & $\begin{array}{c}\text { GDP/capita, } \\
\text { 2010 US\$ }\end{array}$ & $\begin{array}{c}\text { Population } \\
\text { (millions) }\end{array}$ \\
\hline 2015 & 11,322 & 205.96 & 11,322 & 205.96 & 11,322 & 205.96 \\
2020 & 13,383 & 212.36 & 13,123 & 214.56 & 12,530 & 217.59 \\
2025 & 15,725 & 217.27 & 14,928 & 221.99 & 13,288 & 228.76 \\
2030 & 18,445 & 221.01 & 16,913 & 228.00 & 13,935 & 238.36
\end{tabular}

2.2 Demand for ethanol

We estimate future fuel demand for every type of LDV $v$ in a given year $t$, expressed as tonne of oil equivalent (toe), by the equation (2) below

$$
\text { Fuel demand }_{(v, t)}=\text { Transport demand }(t) \times \text { LDV contribution }(v, t) \times \text { Fuel coeff }(v, t)
$$

where Transport demand is the total passenger transport demand for LDV, expressed as pkm, $L D V$ contribution is the percentage of each type of LDV contributing on meeting the passenger transport demand, and Fuel coeff is the fuel consumption coefficient, expressed as toe/pkm.

Total passenger transport demand for LDV comes from the projection based on the panel model in equation (1). The percentage of each type of LDV contributing to the total transport demand is determined based on different datasets, reporting historical Brazilian fleet. The historical fleet was used to compute the average driven distance per type of LDV, and then per passenger using an average LDV occupancy coefficient. Historical data on vehicle numbers is based on

3 The Shared socio-economic pathways (SSP) examine how global society, population and economics might develop in the future (O'Neill et al., 2017; Riahi et al., 2017). They are built upon five different narratives, and we chose to explore in this study the SSP1 ("Sustainability - taking the green road"), SSP2 ("Middle of the road") and SSP3 ("Regional rivalry - a rocky road"). In practice, each SSP scenario shows different curves of population and GPD growth in Brazil, which we use as input data for our future projections. 
the National Emissions Inventory for Road Vehicles (MMA, 2013), Sindipeças and Abipeças (2017) and CETESB (2017), as shown in SI Tables S1 and S2.

There is no historical statistics on driven distance for each type of LDV in Brazil. To calculate the distance driven by Brazilian LDV in a given year, we use the "intensity of use" 4 curves developed by the São Paulo state environmental department (CETESB, 2013). We combine these curves with the average age of vehicles in a given year presented by CETESB (2017), which we bring as SI Table S4. We use both "intensity of use" curves and average age of vehicles from the state of São Paulo as a proxy for the whole country. This assumption is supported by the fact that São Paulo state has the largest LDV fleet numbers in Brazil (i.e. nearly $28 \%$ of the whole country's fleet). The intensity of use curves $y$ per each type of vehicle $v$ in a given year $t$ are estimated by CETESB (2013) by using the equation (2) below where $x$ represents the average age of each type of vehicle; $\alpha, \beta, \gamma$ and $\delta$ are specific parameters applied to each type of vehicle, as presented in SI Table S5.

$$
y_{(v, t)}=\alpha(v) x_{3(v, t)}+\beta_{(v)} x_{2(v, t)}+\gamma(v) x_{(v, t)}+\delta(v)
$$

where $x$ represents the average age of each type of vehicle; $\alpha, \beta, \gamma$ and $\delta$ are specific parameters applied to each type of vehicle, as presented in SI Table S5.

We find the historical passenger transport values per type of LDV by combining the average driven distance per each type of LDV to the historical fleet numbers (SI Table S2). We follow by applying an average occupancy rate of 1.5 persons per LDV trip for passenger cars and one person per motorcycle, as adapted from IPCC (2014). Resulting calculated values of historical LDV passenger transport show the historical contribution of each type of LDV in meeting passenger transport demand in Brazil. Detailed information on these calculated values of

\footnotetext{
4 Intensity of use refers to the annual distance travelled by a vehicle depending on its type (e.g. flex-fuel car) and age. The study on the "intensity of use" curves developed by CETESB (2013) is the most comprehensive estimate available to date in the Brazilian context.
} 
historical LDV passenger transport is presented in SI Table S6. During the period between 2006 and 2016, flex-fuel vehicles increased their contribution from $11.1 \%$ towards $56.3 \%$ (Table 2). Conversely, gasoline-only vehicles had their contribution reduced from $62.3 \%$ to $20.7 \%$ during the 11-year period.

Table 2. Historical percentage of each type of light-duty vehicle contributing to the total passenger transport demand. Data calculated by the authors with detailed information found in SI Table S6.

\begin{tabular}{rrrrrrr} 
& $\begin{array}{l}\text { Ethanol- } \\
\text { only cars }\end{array}$ & \multicolumn{1}{l}{$\begin{array}{l}\text { Flex-fuel } \\
\text { cars }\end{array}$} & $\begin{array}{l}\text { Gasoline- } \\
\text { only cars }\end{array}$ & \multicolumn{1}{l}{$\begin{array}{l}\text { Diesel } \\
\text { cars }\end{array}$} & $\begin{array}{l}\text { Flex } \\
\text { motorcycles }\end{array}$ & $\begin{array}{l}\text { Gasoline-only } \\
\text { motorcycles }\end{array}$ \\
\hline 2006 & $7.24 \%$ & $11.10 \%$ & $62.28 \%$ & $3.99 \%$ & $0.00 \%$ & $15.40 \%$ \\
2007 & $6.06 \%$ & $17.69 \%$ & $55.69 \%$ & $3.88 \%$ & $0.00 \%$ & $16.68 \%$ \\
2008 & $5.03 \%$ & $23.82 \%$ & $49.14 \%$ & $4.07 \%$ & $0.00 \%$ & $17.94 \%$ \\
2009 & $4.20 \%$ & $29.84 \%$ & $43.49 \%$ & $4.18 \%$ & $0.31 \%$ & $17.99 \%$ \\
2010 & $3.46 \%$ & $35.11 \%$ & $38.28 \%$ & $4.50 \%$ & $0.82 \%$ & $17.83 \%$ \\
2011 & $2.85 \%$ & $39.29 \%$ & $33.92 \%$ & $4.82 \%$ & $2.12 \%$ & $16.99 \%$ \\
2012 & $2.36 \%$ & $43.71 \%$ & $30.04 \%$ & $5.04 \%$ & $2.97 \%$ & $15.89 \%$ \\
2013 & $1.76 \%$ & $47.44 \%$ & $27.18 \%$ & $5.12 \%$ & $2.89 \%$ & $15.60 \%$ \\
2014 & $1.35 \%$ & $50.53 \%$ & $24.70 \%$ & $5.17 \%$ & $3.38 \%$ & $14.86 \%$ \\
2015 & $1.05 \%$ & $53.46 \%$ & $22.62 \%$ & $5.00 \%$ & $3.93 \%$ & $13.95 \%$ \\
2016 & $0.75 \%$ & $56.32 \%$ & $20.73 \%$ & $4.82 \%$ & $4.25 \%$ & $13.13 \%$
\end{tabular}

We model the future contributions of each type of LDV in meeting the demand for passenger transport towards 2030 based on their last 11 years' contributions using time as independent variable. Because flex-fuel motorcycles started being produced only in 2009, we model the contribution of the two-wheelers in meeting the passenger transport demand towards 2030 based on their last 5 years contributions. Diesel LDV, showing a relatively stable percentage over the last 11 years, are assumed to maintain the same contribution to demand from 2016 to 2030. We use exponential models for these projections because they present the best fit for the curves of LDV contributions to transport demand. These curves are used to model the LDV contributions towards 2030 while diesel vehicles are kept constant to their contribution in 2016. 
Detailed information on the exponential models is presented on SI Figure S1. Flex-fuel cars, contributing the largest share of passenger transport demand, are assumed to take $100 \%$ of the passenger transport demand reduced by the contributions of ethanol-only cars, gasoline-only cars, diesel LDV, total motorcycles, hybrid and electric vehicles. Similarly, for the twowheelers, flex-fuel motorcycles are assumed to take $100 \%$ of the total motorcycles passenger transport demand reduced by the trend of gasoline-only motorcycles and electric motorcycles. The last variable needed to estimate future fuel demand is the fuel consumption coefficient per vehicle type. We use average fuel consumption coefficients per type of LDV, expressed in tonne of oil equivalent per passenger-kilometer (toe/pkm), as presented in Table 3.

Table 3. LDV average fuel consumption coefficient in 2013.

\begin{tabular}{llrc} 
Type of LDV & \multicolumn{1}{c}{$\begin{array}{c}\text { Fuel } \\
\text { autonomy }\end{array}$} & $\begin{array}{c}\text { Consumption coefficient } \\
\text { (toe/pkm) }\end{array}$ \\
\hline Flex-fuel cars & Gasoline & $11.62 \mathrm{~km} / \mathrm{L}$ & $4.43 \mathrm{E}-05$ \\
Flex-fuel cars & Ethanol & $7.91 \mathrm{~km} / \mathrm{L}$ & $4.30 \mathrm{E}-05$ \\
Gasoline-only cars & Gasoline & $11.07 \mathrm{~km} / \mathrm{L}$ & $4.64 \mathrm{E}-05$ \\
Ethanol-only carsa & Ethanol & $7.91 \mathrm{~km} / \mathrm{L}$ & $4.30 \mathrm{E}-05$ \\
Diesel LDV & Diesel & $9.54 \mathrm{~km} / \mathrm{L}$ & $5.93 \mathrm{E}-05$ \\
Flex-fuel hybrid cars & Gasoline & $14.87 \mathrm{~km} / \mathrm{L}$ & $3.46 \mathrm{E}-05$ \\
Flex-fuel hybrid cars & Ethanol & $10.12 \mathrm{~km} / \mathrm{L}$ & $3.35 \mathrm{E}-05$ \\
Gasoline-only hybrid cars & Gasoline & $16.52 \mathrm{~km} / \mathrm{L}$ & $3.11 \mathrm{E}-05$ \\
Battery electric cars & Electricity & $6.47 \mathrm{~km} / \mathrm{kWh}$ & $8.86 \mathrm{E}-06$ \\
Flex-fuel motorcycles & Gasoline & $43.20 \mathrm{~km} / \mathrm{L}$ & $1.79 \mathrm{E}-05$ \\
Flex-fuel motorcycles & Ethanol & $29.30 \mathrm{~km} / \mathrm{L}$ & $1.74 \mathrm{E}-05$ \\
Gasoline-only motorcycles & Gasoline & $37.19 \mathrm{~km} / \mathrm{L}$ & $2.07 \mathrm{E}-05$ \\
Battery electric motorcycles & Electricity & $20.6 \mathrm{~km} / \mathrm{kWh}$ & $4.17 \mathrm{E}-06$
\end{tabular}

Source: Adapted from COPPE/EPE (2014).

a Ethanol-only cars consumption was based on flex-fuel cars consumption when using ethanol.

In the case of flex-fuel LDV, the market share in the consumption of hydrous ethanol and default fuel blend is not fixed and depends on the relative prices of the two fuel types. To estimate the relationship between fuel prices and hydrous ethanol consumption preference in flex-fuel LDV, we perform a non-linear least-square regression along a logistic curve profile. 
We link the proportion of hydrous ethanol consumption in the total fuel consumption from flex-fuel LDV (y-axis, Figure 4) and monthly observations of the relative prices between hydrous ethanol and the default fuel blend (x-axis, Figure 4). The proportion of ethanol consumption $y$ can be expressed as function of the relative prices between fuels $x$, according to the relation:

$$
y=(b-a) \times\left(1+\mathrm{e}^{*}(x-\alpha)\right)+a
$$

where the low asymptote $a$ is 0.290 , the high asymptote $b$ is 0.840 , the centre point in the logistic curve $\alpha$ is 0.662 , and the slope in the logistic curve $\lambda$ is $37.504\left(\mathrm{R}_{2}=0.851\right)$.

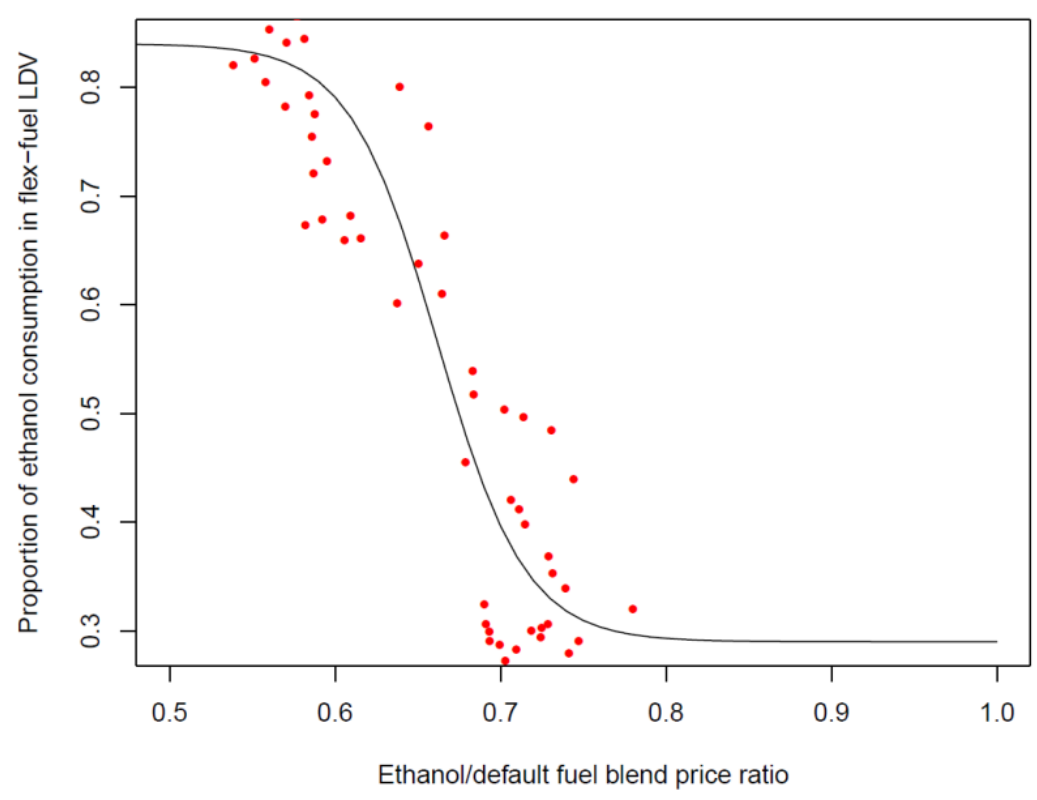

Figure 4. Relative prices between fuels and the proportion of ethanol consumption in flex-fuel cars. Source: Price data from ANP (2017a). Fuel consumption data derived from ANP (2017b) were adjusted by other vehicles consumption using MMA (2013).

Monthly observations - from January 2008 to December 2012 - on average fuel prices come from the National Oil Agency (ANP) in Brazil (ANP, 2017a). The fuel consumption specific for flex-fuel LDV is found by using data on actual hydrous ethanol and default fuel blend 
monthly sales from fuel suppliers (ANP, 2017b). We adjusted this data by respectively reducing fuel consumption from ethanol-only cars and gasoline-only cars and motorcycles found in the National Vehicles Emissions Inventory (MMA, 2013). Because this inventory presents fuel consumption on annual basis, we transformed this data to monthly values. We assumed that monthly fuel consumption fluctuations from ethanol-only cars and gasoline-only cars and motorcycles would follow the same monthly fluctuation pattern of total fuel sales from fuel suppliers in Brazil (ANP, 2017b).

\subsection{Ethanol exports and non-energy ethanol demand}

Although most of the ethanol production in Brazil is consumed domestically, a portion of it is traded in the international market and a smaller fraction is consumed for non-energy purposes. The non-energy ethanol demand has not represented substantial impact in domestic ethanol production historically. Besides, there is no evidence in the international biofuels policy indicating that ethanol exports from Brazil should increase in the short-to-medium term. Therefore, we keep future ethanol exports, as well as the demand for non-energy ethanol at their average level observed in the period 2008-2017 (EPE, 2006, 2018a).

Accordingly, we add 2.5 billion litres for ethanol exports and 1.2 billion litres for non-energy ethanol demand to our projections of ethanol demand in the domestic transport sector. These numbers are consistent with the approach used by the Energy Research Enterprise (EPE) in Brazil (EPE, 2018b) for their projections. By 2030, EPE expects 2.7 billion litres of ethanol exports and 1.4 billion litres of non-energy ethanol demand. Details of historical ethanol exports and non-energy ethanol demand are presented in SI Table S7.

\subsection{Land-use modeling framework}


Land-use implications are assessed by projecting Brazil's land-use change and agricultural outputs through 2030, taking into account the future scenarios of ethanol demand. For this purpose, we use the GLOBIOM-Brazil model, a bottom-up global partial equilibrium economic model of agriculture, forestry and bioenergy sectors, specifically adapted to the Brazilian context (Soterroni et al., 2018; Soterroni et al., 2019). Among other specificities, for this study GLOBIOM-Brazil includes the agro-ecological zoning (AEZ) for sugarcane in Brazil, developed by Manzatto et al. (2009) and established by a Federal law in 2009. The AEZ for sugarcane identifies the areas where sugarcane crops can take place, and areas with restrictions regarding soil, climate, topography, water and others. It also prohibits sugarcane expansion in ecologically sensitive areas, like the Amazon and the Pantanal biomes. The AEZ for sugarcane was implemented in the model as an economic incentive by reducing production costs, from 2010 onward, proportionally to the AEZ suitability level at a given grid cell. Unsuitable areas do not have any economic incentives. The model also totally restricts new land conversions to sugarcane after 2010 in the Amazon and the Pantanal.

GLOBIOM-Brazil is based on the global version of the IIASA's global biosphere management (GLOBIOM) model (Havlík et al., 2011). It optimizes the competition for land at the grid-cell level by maximizing the sum of consumer and producer surpluses subject to resources and technology availability, as well as policy constraints (Valin et al., 2013). Final demand, processing quantities, associated prices and international trade flows are modelled at the regional level, for 30 global economic regions, simulating 18 crop products, seven livestock products and five forestry products (Havlík et al., 2014). Crop productivity is defined by the EPIC model (Williams, 1995), and livestock productivity is defined by the RUMINANT model (Herrero et al., 2013; Herrero et al., 2008). GLOBIOM-Brazil also endogenously adjusts crops and livestock productivities by reallocating production to more suitable areas or changing the management and production systems (e.g. lower to higher input; extensive to semi-intensive) 
(Havlík et al., 2014). Land-use change and agricultural output variables are modeled through 3,001 pixels in Brazil, given by $0.5^{\circ}$ by $0.5^{\circ}$ uniform grid, with a spatial resolution of approximately $50 \mathrm{~km}$ x $50 \mathrm{~km}$ (Soterroni et al., 2018). In this study, the model is recursively run for 10-year time steps between the years 2000 and 2030.

Our approach is based on the development and simulation of scenarios that consider different possible ethanol demand trajectories in Brazil. Future demand for other products from landuse sectors (e.g. livestock) in each of the 30 worldwide economic regions is exogenously based on population and GDP growth from the SSP2 scenario (Dellink et al., 2017). Such demand is endogenously adjusted in the model by interdependencies from land-use sectors. Income elasticities come from the USDA and food preferences from the FAO (Alexandratos and Bruinsma, 2012), as adapted in (Valin et al., 2014). Land use policy in Brazil is assumed to follow a scenario of imperfect or partial illegal deforestation control in the Amazon and the Cerrado biomes. The imperfect control is based on a probability of enforcement that restricts the deforestation in each pixel, as presented by Soterroni et al. (2018) in their "IDCImperfect3 Scenario". This scenario also assumes full control of illegal deforestation in the Atlantic Forest biome. Additionally, no forest restoration is projected to occur in this configuration of the landuse and competition modelling. Such approach assumes an overall scenario of governance in Brazil that i) captures the historical deforestation trends by projecting 16.4 Mha and 6.2 Mha of accumulated deforestation in the Amazon biome during the periods 2001-2010 and 20112020, respectively5; and ii) permits to detect direct LUC to sugarcane due to the expansion of ethanol consumption in Brazil.

Starting in the year 2000, we compare the model outputs for the first period of simulation (i.e. 2010) with official statistics from the Brazilian government in regards to accumulated 
deforestation, agricultural production and land-use. Results of the validation process are presented in SI Figures S2-S4.

3. Future scenarios of ethanol demand

Different factors need to be explicitly considered for our ethanol demand projections: population and GDP growth, the demand for light vehicles passenger transport, default fuel blend mandates, relative prices between ethanol and the default fuel blend, the composition of the fleet and improvements in fuel consumption efficiency. Since these factors are influenced by the macroeconomic context and policy interventions, we develop three potential scenarios of ethanol demand in Brazil for 2030. These are called Renewable fuels oriented (RFO), Business as usual (BAU), and Fossil fuels oriented (FFO). The scenarios are mapped with the macroeconomic elements of the three Shared Socioeconomic Pathways (SSP) SSP1 ("Sustainability - taking the green road"), SSP2 ("Middle of the road") and SSP3 ("Regional rivalry - a rocky road"), as described by Riahi et al. (2017). GDP and population assumptions then directly determine projections of passenger transport demand for each scenario based on the panel model from Section 2.1. The other drivers of ethanol demand associated to the scenarios are presented in Table 4. These present the following assumptions:

Table 4. Assumptions for future scenarios of ethanol demand in Brazil by 2030.

\begin{tabular}{l|ccc} 
& $\begin{array}{c}\text { Scenario 1 } \\
\text { Renewable Fuels } \\
\text { Oriented (RFO) }\end{array}$ & $\begin{array}{c}\text { Scenario 2 } \\
\text { Business as Usual } \\
\text { (BAU) }\end{array}$ & $\begin{array}{c}\text { Scenario 3 } \\
\text { Fossil Fuels Oriented } \\
\text { (FFO) }\end{array}$ \\
\hline $\begin{array}{l}\text { Macroeconomic } \\
\text { drivers and pkm } \\
\text { demand }\end{array}$ & Based on SSP1 & Based on SSP2 & Based on SSP3 \\
$\begin{array}{l}\text { Default fuel blend } \\
\text { mandate }\end{array}$ & $35 \%$ & $27 \%$ & $20 \%$ \\
& $60 \%$ & $67.8 \%$ & $75 \%$
\end{tabular}




\section{Average price ratio between ethanol and the fuel-blend \\ Presence of hybrid and electric vehicles \\ Net improvement on fuel consumption}

$12 \%$

$1.53 \%$ p.a.
$4 \%$

$1 \%$ p.a.
$1.33 \%$

$0 \%$ p.a.

- Fuel blend mandate: Because the default fuel blend mandate is currently $27 \%$, BAU scenario would maintain the same situation. Blend mandate on RFO scenario would be increased to $35 \%$, while FFO scenario would have the blend mandate reduced to $20 \%$. If the reduction to $20 \%$ has already been observed in the recent past (Figure 1b), the blend mandate has never been over $27 \%$ in Brazil. There has been unsuccessful attempts of reviewing the current policy and increasing the blend mandate to $40 \%$ (OECD and FAO, 2018)6. Therefore, we assume the 35\% blend mandate to be a plausible yet progressive measure, in line with the RFO scenario's narrative.

- Fuel prices: We model the relative prices between ethanol and default fuel blend for the BAU scenario assuming the potential fuel price effects from the National Biofuels Policy (RenovaBio). These potential effects were reported by the Brazilian government though a technical note in May 2018. According to this technical note (MME, 2018), by 2028 the average prices of hydrous ethanol (i.e. ethanol used directly in flex-fuel LDV) would be reduced by $2.1 \%$. Average prices of anhydrous ethanol (i.e. ethanol used in the default fuel blend) would be reduced by $2.3 \%$, and average prices of gasoline A (i.e. pure gasoline before blending) would be increased by $0.7 \%$. This relative

\footnotetext{
6 The OECD-FAO Agricultural Outlook 2018-2027 reflected early versions of the National Biofuels Policy (RenovaBio) that included progressive blending targets of anhydrous ethanol with gasoline (i.e. $30 \%$ by 2022 and $40 \%$ by 2030, in volume terms). RenovaBio was nonetheless approved as Law no. 13576 in December 2017 without specifying such targets.
} 
stability of gasoline prices expected by the Brazilian government is also consistent to the trend suggested by the World Energy Outlook 2017 (OECD, 2017). The international institute expects oil prices to stay "lower for longer" not only in the next few years but possibly for a decade or so. We take into account these potential effects from RenovaBio, and we note that the average price ratio between ethanol and default fuel blend during the first half of 2018 in Brazil was 69.1\%. BAU scenario therefore assumes an average price ratio of $67.8 \%$ by 2030 , remaining approximately the same in the short to medium-term. The RFO scenario would have average prices more favorable for ethanol consumption in comparison to the fuel blend, i.e. in the $60 \%$ mark, whereas the average price ratio in the FFO scenario would be $75 \%$.

- Hybrid and electric vehicles (HEV): The introduction of HEV in Brazil currently faces a slow pace, with only 3,296 new registered vehicles in 2017 , or $0.2 \%$ of the market share (ANFAVEA, 2018). We have based future assumption on the 2050 Energy Demand report (EPE, 2016) for the BAU scenario. We assume 3\% of hybrid vehicles (considering half of them being flex-fuel hybrid vehicles); $0.5 \%$ of battery electric vehicles; and $0.5 \%$ battery electric motorcycles in the LDV passenger transport demand mix by 2030. The introduction of HEV would be three times faster in the RFO scenario, assuming favorable policy-oriented strategies supporting the fleet renewal, and the combustion engine on hybrid vehicles would be flex-fuel. Conversely, FFO scenario would show by 2030 an introduction of HEV three times slower than what is expected in the BAU scenario, with hybrid vehicles having gasoline-only combustion engines.

- Fuel consumption efficiency for LDV: we assume BAU scenario to present a net reduction of $1 \%$ per year towards 2030, following the approach from EPE (2016). The FFO scenario would have no improvement in the average fuel consumption efficiency towards 2030. In line with the SSP3 narrative (Riahi et al., 2017), we consider that 
future technological efforts in increasing the efficiency of LDV fuel consumption would not be coupled with improvements in road transport infrastructure. Increasing traffic congestion would result in lower fuel consumption efficiency, since LDV would take longer in 2030 to travel the same distances as in 2013. Conversely, the fuel efficiency trajectory for the RFO scenario is based on the target from the Global Fuel Economy Initiative (GFEI, 2018) that expects countries to improve LDV fuel economy by $50 \%$ between 2005 and 2050 . Because our baselines are the average coefficients from 2013, we assume in this scenario an improvement on fuel consumption efficiency of $1.53 \%$ per year towards 2030 .

In order to test the influence across scenarios of the different drivers presented in Table 4, we also perform a sensitivity analysis. We test the impact of varying each parameter separately for the FFO, BAU and RFO scenarios while keeping the other variables constant to the values assumed for the BAU scenario.

\section{Results}

\subsection{Passenger transport demand projections for LDV}

The demand for LDV passenger transport in Brazil was 5,259 pkm per capita in 2013 - our reference year for transport demand projections. Results demonstrate a considerable increase in passenger transport demand towards 2030 for all scenarios: from 5,964 pkm per capita in FFO to 7,467 pkm per capita in RFO. The RFO scenario results in the highest demand for transport because it also shows the highest projection of GDP, according to de SSP1 scenario for Brazil presented in Table 1. We report projections from the data panel analysis of passenger transport demand for LDV in Brazil towards 2030 in Table 5. 
Table 5. Passenger transport demand projections for LDV in Brazil.

\begin{tabular}{ccccccc} 
& \multicolumn{2}{c}{ FFO / SSP3 } & \multicolumn{2}{c}{ BAU / SSP2 } & \multicolumn{2}{c}{ RFO / SSP1 } \\
& $\begin{array}{c}\text { pkm per } \\
\text { capita }\end{array}$ & $\begin{array}{c}\text { Total pkm } \\
\text { (billions)a }\end{array}$ & $\begin{array}{c}\text { pkm per } \\
\text { capita }\end{array}$ & $\begin{array}{c}\text { Total pkm } \\
\text { (billions)a }\end{array}$ & $\begin{array}{c}\text { pkm per } \\
\text { capita }\end{array}$ & $\begin{array}{c}\text { Total pkm } \\
\text { (billions)a }\end{array}$ \\
\hline 2013 & 5,259 & 1,064 & 5,259 & 1,064 & 5,259 & 1,064 \\
2020 & 5,476 & 1,192 & 5,683 & 1,219 & 5,773 & 1,226 \\
2025 & 5,740 & 1,313 & 6,302 & 1,399 & 6,570 & 1,428 \\
2030 & 5,964 & 1,422 & 6,966 & 1,588 & 7,467 & 1,650
\end{tabular}

a Based on population projections from each SSP (Table 1).

\subsection{Future fuel demand}

As presented in the methods section, we find future fuel demand by first allocating total passenger transport demand across the LDV fleet in Brazil. We show in figure 5 the projected evolution over time of the contribution from each LDV in Brazil in meeting the total demand for passenger transport. Flex-fuel cars, responsible for meeting 53.5\% of the Brazilian LDV passenger transport demand in 2015, will keep increasing their contributions to $76.6 \%$ in the FFO scenario (Figure 5a) and 74.3\% in the BAU scenario (Figure 5b) towards 2030. Because the RFO scenario shows a faster introduction of hybrid and electric vehicles, flex-fuel cars' contribution to the passenger transport demand mix would start to be reduced after achieving a peak of $69.5 \%$ in 2025 (Figure 5c). On the other hand, gasoline-only cars - already in declining numbers - would keep reducing their percentage for meeting passenger transport demand. Similarly, the share of flex-fuel motorcycles and gasoline-only motorcycles would decrease, although at a slower pace. Nonetheless, the contribution of total motorcycles in meeting LDV passenger transport demand is slightly decreasing from $17.9 \%$ in 2015 to $13.2 \%$ in 2030 across all scenarios. 

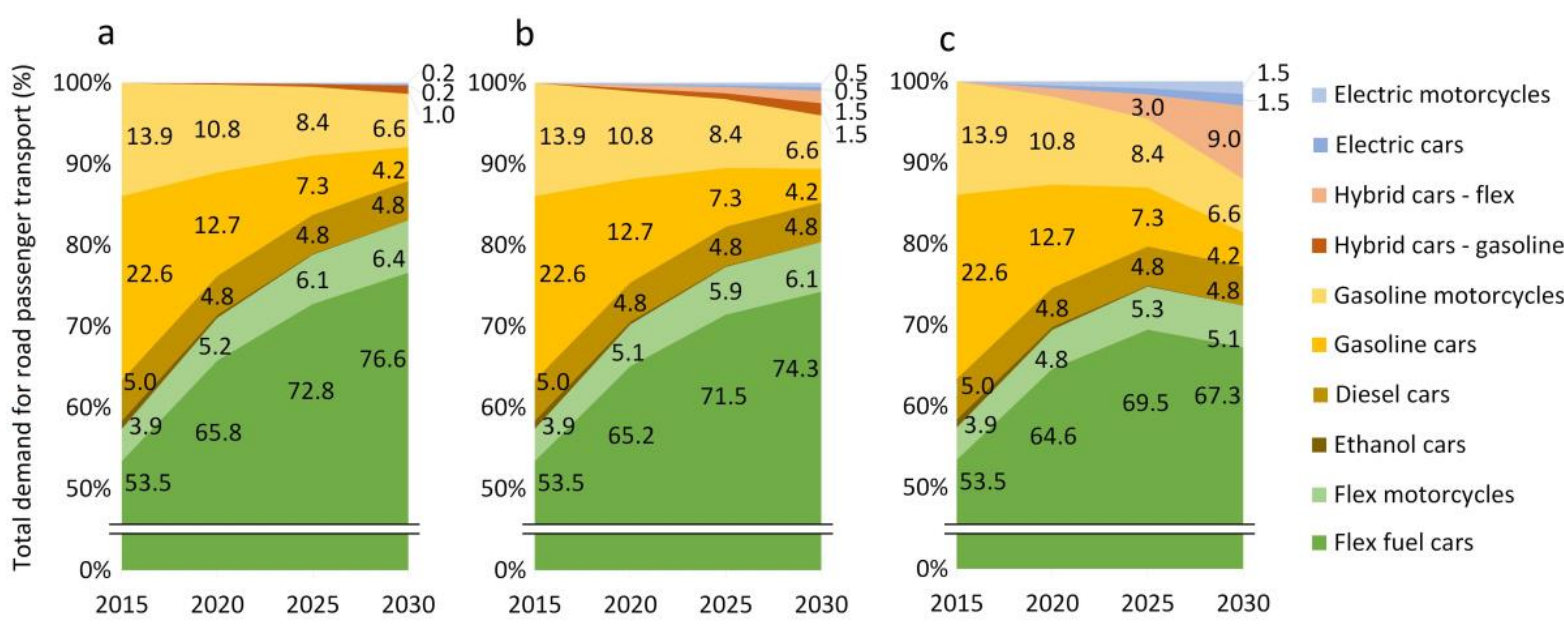

Figure 5. Contribution of each type of LDV in meeting road passenger transport demand in the (a) Fossil fuels oriented scenario, (b) Business as usual scenario, and (c) Renewable fuels oriented scenario. Numbers correspond to the percentage of contribution of each vehicle type in meeting total LDV passenger transport demand.

Transforming fleet and transport demand development into fuel consumption leads to an overall increase in fuel demand from LDV in Brazil. Ethanol demand would increase to 17.5 million tonnes of oil equivalent (Mtoe) in the FFO scenario, 24 Mtoe in the BAU, and 34.4 Mtoe in the RFO scenario in 2030 (Figure 6). Respectively, these projections are 11\%, 53\%, and $119 \%$ higher than the consumption observed in 2018. In terms of ethanol volume (i.e. combining volume of anhydrous ethanol to volume of hydrous ethanol7), these numbers represent a future demand of 33.8 billion litres in the FFO scenario, 46.6 billion litres in the BAU and 67 billion litres in the RFO scenario. When incorporating ethanol exports and nonenergy ethanol demand, these numbers respectively rise to 37.4 billion litres, 50.2 billion litres and 70.7 billion litres in 2030 .

7 Because hydrous and anhydrous ethanol have different energy content, combined numbers of hydrous and anhydrous ethanol using one equivalent volume metric would slightly differ to the ones presented here. 


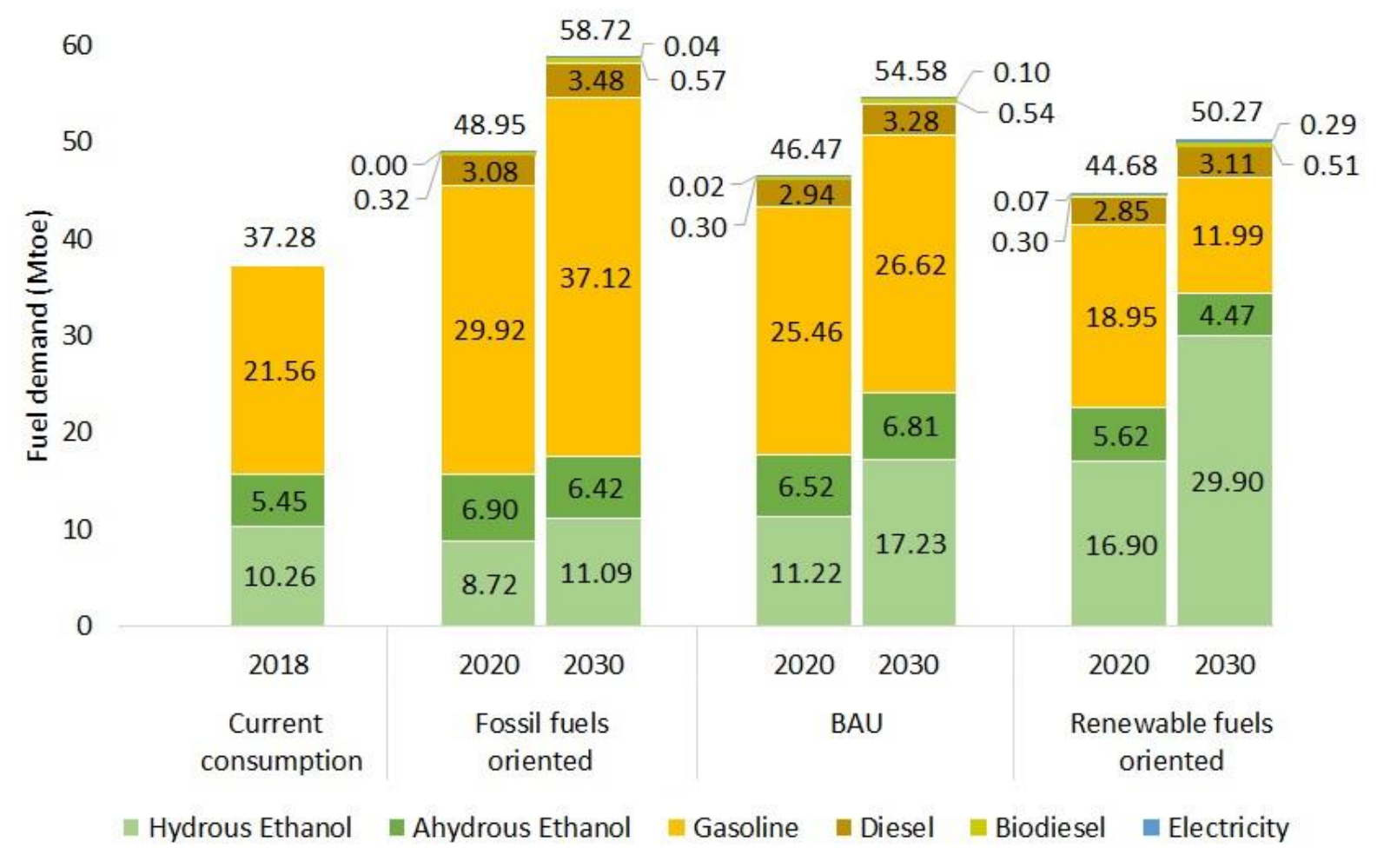

Figure 6. Future fuel demand across scenarios in comparison to consumption numbers in 2018, according to EPE (2019). There is no data on consumption of diesel, biodiesel and electricity specifically for the LDV fleet in 2018. Future numbers of diesel and biodiesel demand consider a $15 \%$ biodiesel-diesel blend mandate, in terms of volume, regardless on the scenario. Fuel demand is expressed in million tonnes of oil equivalent (Mtoe).

Detailed information on the final ethanol demand curves fed into GLOBIOM-Brazil is presented in SI Table S8-S10. This consider the projected demand for ethanol in the light-duty vehicles transport sector commented above, as well as exports and the non-energy ethanol demand are.

\subsection{Land-use implications}

The future demand for ethanol in Brazil triggers a large expansion of domestic production of sugar cane. According to our projections, between 2010 and 2030, sugarcane production would increase by $295 \mathrm{Mt}$ in the FFO scenario, $454 \mathrm{Mt}$ in the BAU and $705 \mathrm{Mt}$ in the RFO scenario 
(Figure 7a). Similarly, sugarcane area would expand by 1.6 Mha in the FFO scenario, 3.1 Mha in the BAU and 5.4 Mha in the RFO scenario during the period 2010-2030 (Figure 7b). The comparison between extreme scenarios of ethanol demand shows a difference in sugarcane area of 3.8 Mha by 2030. In 2026, the Brazil's sugarcane area is projected to be between 9.4 and 12.3 Mha according to the FFO and RFO scenarios, respectively. Projections from the Ministry of Agriculture, Livestock and Supply (MAPA) in Brazil (MAPA, 2017) estimate a sugarcane area ranging from 8.2 to 12.8 Mha for the same year. More importantly, regardless the scenario of ethanol demand, sugarcane expansion in Brazil would present no considerable effect in the area or production of other crops (Figure 7).
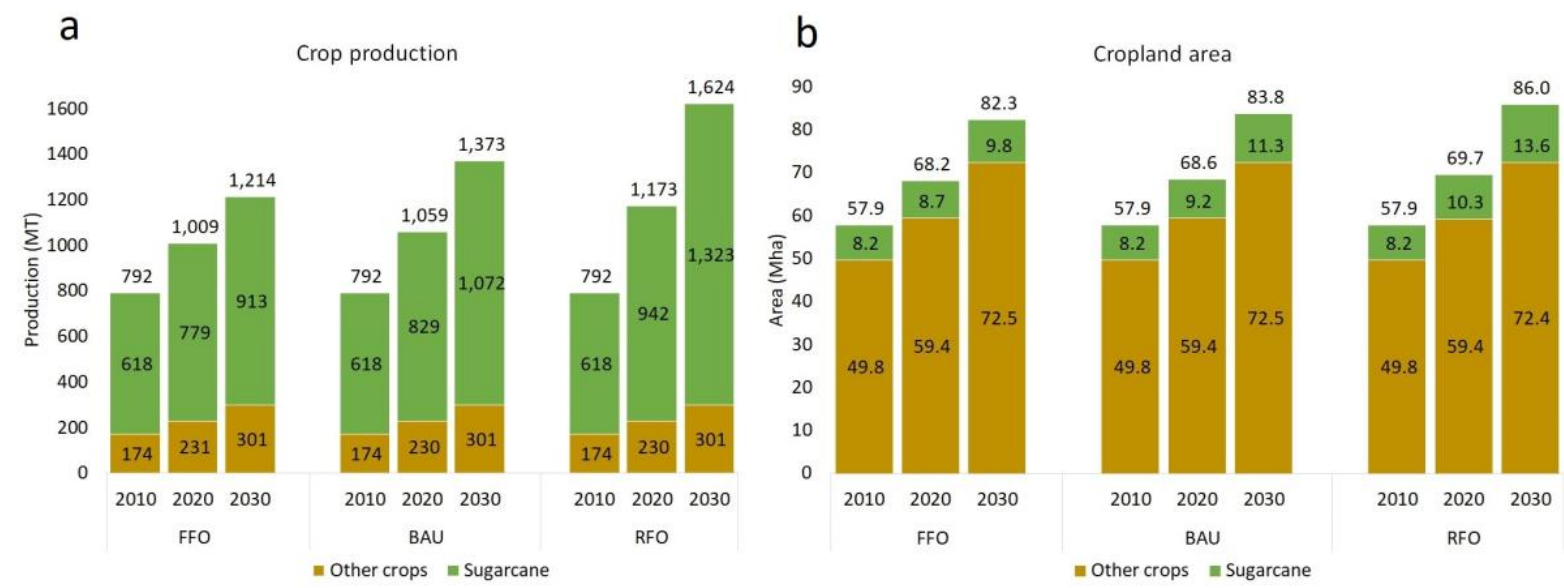

Figure 7. Cropland harvested area (a) and crop production (b) changes between 2010 and 2030 based on GLOBIOM-Brazil simulations.

Cattle herd would increase 55 million of tropical livestock units (TLU) between 2010 and 2030, with no considerable difference across scenarios. However, the expansion of pastureland area shows a different dynamic. Pastureland area would decrease or remain constant in all biomes after 2020. The RFO scenario projects less 2.7 Mha of pasture in comparison with the FFO projections. The greater is the ethanol demand, the smaller is the projected pasture. This intensification would lead to a rise stocking rates by $25.8 \%$ in the FFO scenario, $26.4 \%$ in the 
BAU and $27.2 \%$ in the RFO scenario between 2010 and 2030. This projected rise in stocking rates is on par with a recent empirical study (Dias et al., 2016). Using remote sensing imagery combined with census and inventory data, the authors show that the stocking rate in Brazil has increased by $28 \%$ per decade (50\% in the Amazon) between 1990 and 2010 . Note that a small growth in stocking rate liberates enough pasture area to accommodate the expansion of ethanol consumption, and thus of sugarcane crop area, across scenarios. Detailed evolution of cattle herd numbers, pastureland area and stocking rates is presented in Table 6.

Table 6. Evolution of cattle herd numbers, pastureland area and stocking rates across scenarios between 2020-2010 and 2030-2010. Abbreviation: MTLU = millions of tropical livestock units; Mha = million hectares; TLU/ha = tropical livestock units per hectare.

\begin{tabular}{l|cccccc} 
& \multicolumn{2}{|c}{ FFO } & \multicolumn{2}{c}{ BAU } & \multicolumn{2}{c}{ RFO } \\
& $2020-2010$ & $2030-2010$ & $2020-2010$ & $2030-2010$ & $2020-2010$ & $2030-2010$ \\
\hline Cattle herd (MTLU) & 27.3 & 55.2 & 27.2 & 55.2 & 27.0 & 55.3 \\
Pastureland area (Mha) & 21.7 & 22.7 & 21.5 & 21.5 & 20.9 & 20.0 \\
Stocking rates (TLU/ha) & 0.054 & 0.165 & 0.055 & 0.169 & 0.056 & 0.174
\end{tabular}

Overall, our results indicate that most of the sugarcane expansion between 2010 and 2030 occurs at the expense of grassland, with a loss of 0.72 ha of pastures for each additional hectare of sugarcane. There are many studies corroborating this result, showing that the vast majority of direct land use change into cropland (and sugarcane plantations, in particular) in Brazil during the last decades occurred on pastureland. For two recent studies using very different approaches, see van der Hilst et al. (2018), Zalles et al. (2019); for a review, see Bordonal et al. (2018). 
More importantly, our results suggest that sugarcane expansion would have limited direct and indirect impacts on total native vegetation area in Brazil. Comparing the land-use of the minimal (FFO) to maximum (RFO) ethanol demand scenarios by 2030 , deforestation only increases 0.18 Mha. Increase in deforestation for the Cerrado biome is 0.13 Mha and for the Amazon biome is 0.03 Mha (as shown in more detail in SI Table S11). To put into context, the expansion of sugar cane area by 2030, from 1.6 Mha in the FFO scenario to 5.4 Mha in the RFO, would result in loss of 0.18 Mha of native vegetation - which represents $4.8 \%$ of this sugarcane expansion (see Table 7, particularly in the comparison between RFO and FFO scenarios). These results therefore suggest a weak correlation between sugarcane expansion and deforestation growth in Brazil, in particular in the Amazon. Quantitatively, each additional sugarcane hectare results in a loss of 0.05 ha of native vegetation ( $72 \%$ in the Cerrado and $17 \%$ in the Amazon; see SI Table S11). The addition loss of grass, shrubs and secondary vegetation areas (see "non-productive land" in Table 7, last column), increases the potential loss of native vegetation to 0.24 ha per hectare of sugarcane. However, this last figure is probably overestimated since large areas of unproductive degraded pasture are also included under the label "non-productive land". In any case, this result compares well with Ferreira Filho and Horridge (2014) and van der Hilst et al. (2018) who found, respectively, a potential loss of 0.14 and 0.26 ha of native vegetation per additional hectare of sugarcane.

As for the other crops, our projections also show a small impact: a potential loss of 0.04 ha of other crops for each additional hectare of sugarcane. Van der Hilst et al. (2018) projects a loss 0.06 ha for the same period. Rudorff et al. (2010) Adami et al. (2012) found larger losses of annual crops (respectively, 0.40 and 0.25 ha for each new hectare of sugarcane). They argue that most of the sugarcane expansion computed as being over agricultural land occurs actually over pastureland, since pastures are often converted to an annual summer crop before sugarcane is planted. 
Table 7. Evolution of the land-use classes by 2030 for the BAU and RFO scenarios, in comparison to the FFO scenario, in million hectares.

\begin{tabular}{lcccc} 
& BAU-FFO & BAU-FFO & RFO-FFO & RFO-FFO \\
& $\Delta(\mathrm{Mha})$ & $\Delta(\%) \mathrm{a}$ & $\Delta(\mathrm{Mha})$ & $\Delta(\%)_{\mathrm{a}}$ \\
\hline Sugarcane & 1.44 & $100 \%$ & 3.77 & $100 \%$ \\
Other crops & -0.01 & $-0.7 \%$ & -0.15 & $-4.1 \%$ \\
Planted forestb & -0.01 & $-0.7 \%$ & -0.02 & $-0.7 \%$ \\
Native vegetation & -0.10 & $-6.9 \%$ & -0.18 & $-4.8 \%$ \\
Non-productive landc & -0.12 & $-8.4 \%$ & -0.71 & $-18.8 \%$ \\
Pasture & -1.20 & $-83.3 \%$ & -2.70 & $-71.7 \%$
\end{tabular}

aln relation to the sugarcane expansion. bOr short rotation tree plantation. cOr mosaics of natural vegetation and areas converted from agriculture but not currently under production.

4.4 Sensitivity analysis on the variables influencing ethanol demand

As presented above, results of ethanol demand for LDV passenger transport sector in Brazil for BAU scenario by 2030 is 46.6 billion litres. Having this value as reference (centre line, figure 6), our sensitivity analysis shows that price ratio between hydrous ethanol and the default fuel blend is the parameter showing strongest influence on final demand for ethanol. If average prices in 2030 are in the $60 \%$ ratio (RFO scenario assumption), ethanol demand on BAU scenario would jump from 46.6 to 69.9 billion litres. Conversely, prices by 2030 in the $75 \%$ ratio (FFO scenario assumption) would reduce ethanol demand in the BAU scenario to 35.7 billion litres. 


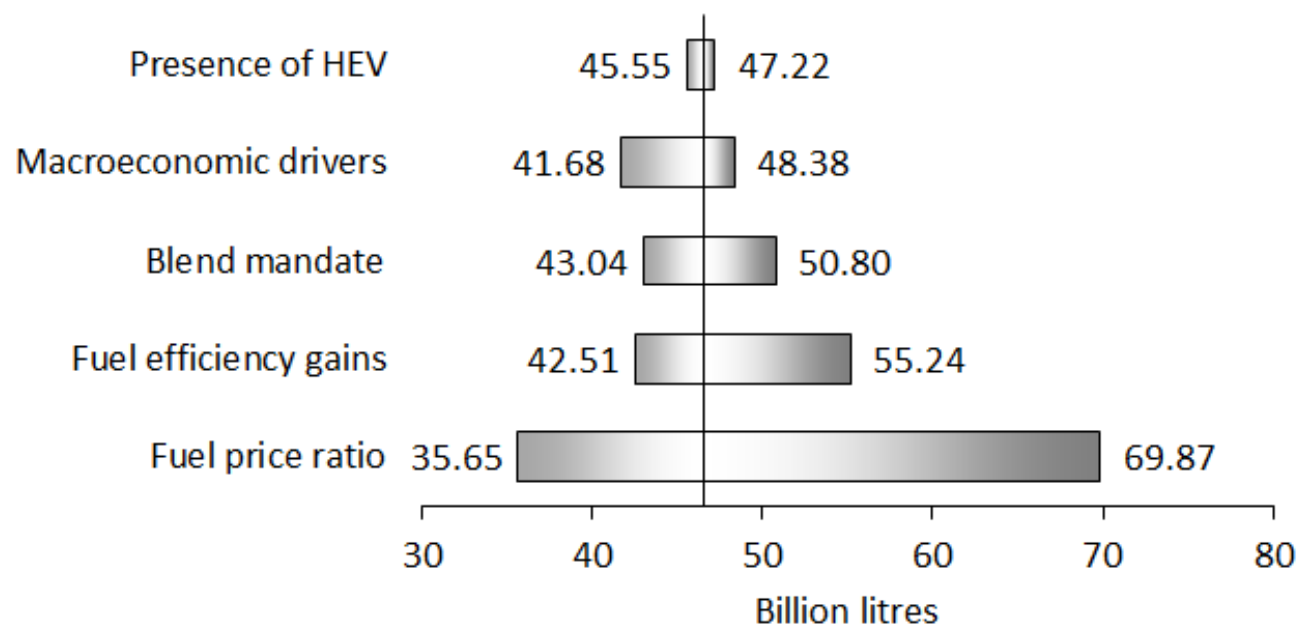

Figure 8. Sensitivity analysis on the effects of using other scenarios' variables on ethanol demand at BAU scenario in 2030. Centre line represents the 46.57 billion litres of combined hydrous ethanol and anhydrous ethanol demand by 2030 in the BAU scenario.

\section{Discussion}

Our results provides more clarity on the prospect on future ethanol demand in Brazil, influenced by different macroeconomic and policy drivers, and its implications for land-use competition. Our projection of ethanol demand for the transport sector in Brazil accounts for 46.6 billion litres in the BAU scenario by 2030 . This is consistent with recent official projections from EPE, with 45.3 billion liters of ethanol demand in their medium growth scenario by 2030 (EPE, 2018b). Our results for a BAU scenario also reflect projections from the International Energy Agency (IEA). In their World Energy Outlook (OECD, 2017), the organization predicts an $85 \%$ increase in the ethanol demand in Brazil by 2040 , compared to the consumption of 28 billion litres observed in 2016, resulting in a demand of 51.8 billion litres. As a matter of comparison, if we extend the projections to 2040 using our same methods, ethanol demand would rise to 51.6 billion litres in the BAU scenario. Extended ethanol projections to 2050 using our fuel demand model can be consulted in SI Table S12. 
Institutional forecasting exercises as above are often structured around single scenarios or alternatives with limited influencing variables. The three scenarios we have developed illustrate the extent to which different macroeconomic and policy drivers could affect future ethanol demand in Brazil. Although our Fossil fuel oriented and Renewable fuel oriented scenarios take strong assumptions on key driver changes, they draw realistic alternative futures and show the range of possible future outcomes. As far as regulation or governmental programs are concerned, the narratives and parameters assumed in the design of our scenarios have already been observed in the past (for instance, see Figures $1 \mathrm{~b}$ and $1 \mathrm{c}$ when it comes to shifting blend mandates and fuel prices ratio). Otherwise, our assumptions have also been considered to be implemented (such as the progressive ethanol blend mandate targets of $30 \%$ and $40 \%$ proposed in early versions of RenovaBio and later dismissed). We considered in our modelling framework that compressed natural gas $(\mathrm{CNG})$ consumption would continue to show no considerable impact on the demand for default fuel blend or ethanol within the LDV fleet in Brazil. In case unexpected policies and regulations start to support the introduction of $\mathrm{CNG}$ vehicles in Brazil, projections of future demand for ethanol could change. For hybrid and electric vehicles, our most optimistic scenario considers an introduction of this technology three-fold faster than what is expected by institutional reports (EPE, 2016). An introduction of hybrid and electric vehicles beyond our optimistic assumptions would likewise affect our projections of future demand for ethanol.

An ever-growing demand for food, feed and biofuel triggered the competition for land and a spatial reorganization of land use in Brazil (Melo et al., 2018). Low-productive, extensive cattle ranching is being increasingly replaced by higher-income (per unit of area) crops, like soybeans or sugarcane (Martha et al., 2012; Melo et al., 2018). This process could have a negative impact on food production, and directly or indirectly generate the suppression of native vegetation areas - as presented, for example, by Lapola et al. (2010). Our results, which cover the period 
of 2010-2030 and include different scenarios of sugarcane ethanol demand, do not support this narrative in the case of sugar cane expansion. We found that sugarcane ethanol production is projected to expand mostly at the expense of pastures, with little direct or indirect impact on other crops and on native vegetation, including forests in the Amazon. Naturally, this result depends on the assumption that the AEZ for sugarcane will continue to be enforced. It is also strongly driven by the assumption that Brazil will keep supporting an increase of cattle ranching efficiency, as observed in the recent past. Cohn et al. (2014) provided illustration on how policy incentives could help boosting the intensification potential of Brazilian pasture. This process helps in our simulations sparing enough land to accommodate the expansion of ethanol production. Such assumption is supported by current trends and anticipated to continue during the next decades, according to Adami et al. (2012), Bordonal et al. (2018), and references there in.

According to our simulations, sugarcane area expands substantially as demand for ethanol increases across scenarios. Our results compare well in that extent to the estimates from van der Hilst et al. (2018). Their models suggest an expansion of sugarcane crops in Brazil between 11.9 and 13.6 Mha by 2030 whereas our scenarios indicate an expansion between 9.8 and 13.6 Mha during the same period. However, van der Hilst et al. (2018) only considers one single exogenous ethanol demand scenario, based on the World energy outlook 2014 from IEA and OECD. Similar to Lapola et al. (2010), their approach fails to consider effects of potential macroeconomic drivers and regulatory programs on future demand for ethanol. Conversely, van der Hilst et al. (2018) designs different scenarios to test the effects of mitigation strategies on land-use change. They present interesting results in the supply-side measures of agricultural productivity and second-generation ethanol production, for instance.

Although we feed GLOBIOM-Brazil with three different ethanol demand scenarios, for modeling the land use competition in this study we assume an overall scenario of governance 
in Brazil. This governance scenario captures the historical deforestation trends, as described by Soterroni et al. (2018) in their imperfect illegal deforestation control scenarios. In this sense, more optimistic or pessimistic governance scenarios could also develop on the land use impact side. They depend on how the country complies with its land-use policy commitments, such as the control of illegal deforestation and the AEZ for sugarcane. These circumstances are particularly relevant in the current political context of transitioning governments and the uncertainties that it brings to the future of the commitments made by Brazil to the Paris Agreement.

The results of our analysis are also contingent to some choices made in the scenario design. As explained in the methods section, we kept the demand patterns for other agriculture products aligned with the assumptions of the SSP2 scenario. Demand for other agriculture products remains endogenous to market prices, and therefore react to the different level of pressure on land coming from the sugarcane demand level. However, the actual land-use outputs for our RFO and FFO scenarios could differ more significantly if we were also using SSP1 or SSP3 for demand projections of other agriculture products in GLOBIOM-Brazil. Nonetheless, this potential disparity on future land-use would be caused by other agriculture products and not driven only by the difference in ethanol demand - which is the focus in this study. Another source of scenario uncertainty is the influence of the international sugar market. A shift away from the historical patterns on the international sugar demand could influence the supply of ethanol domestically. This would have consequences on ethanol prices that our scenarios do not directly investigate, even if this factor played a similar role to the change in fossil fuel price (through the price ratio of Figure 4). The fluctuation around the volumes of ethanol exports from Brazil could likewise affect our projections of ethanol demand, if they occur differently from our assumptions in this regard. The potential deployment of other sources of biofuels in Brazil, such as corn-based ethanol, and second-generation ethanol (from sugarcane or other 
crops) would have direct influence on the first generation sugarcane ethanol demand we focus on here. The land-use implications of a stronger development of these types of fuels in the Brazilian context should be subject of future research. Finally, we note the uncertainties associated to partial equilibrium models (Wicke et al. 2015) and indirect land-use change modelling (Verstegen et al. 2016). The results proposed here should be approached as an illustration of the impacts of possible scenarios and not as a policy assessment, which would require a different set of scenarios and sensitivity analyses.

\section{Conclusions and Policy Implications}

We thoroughly investigate how different macroeconomic and policy drivers could influence the future demand for ethanol in Brazil and the associated land-use consequences. We show how ethanol demand is sensitive to GDP and population growth, fuel blend mandates, fuel prices, fleet composition and efficiency gains in fuel consumption. Future developments of these influencing factors could increase demand for sugarcane ethanol between $13 \%$ and $114 \%$ above the consumption observed in 2018. Such increase could drive up sugarcane cultivated area, already stimulated by increased sugar demand for food, by an extra 1.2 Mha to 5 Mha. Although sugarcane area is substantially smaller than the pastureland area in Brazil, a larger sugarcane expansion, would increase to some extent the pressure on pasture land and incentivize higher cattle stocking rates. Moving from the low to high demand scenarios only marginally impact net native vegetation area. Sugarcane expansion in response to higher ethanol demand is expected to take place primarily over pasture and to a lesser extent over nonproductive lands. These results suggest that Brazil can meet future demand for ethanol with limited effects on other crops and native vegetation, if the ethanol industry continues to follow the sugarcane AEZ. 
Acknowledgments

M. A. U. de Andrade Junior gratefully thanks the National Council for Scientific and Technological Development - CNPq (Brazil) scholarship number 233763/2014-7, and the State Department of Sustainable Economic Development - SDS, Santa Catarina (Brazil). This research was developed as part of the Young Scientists Summer Program 2017 organized by the International Institute for Applied Systems Analysis - IIASA, Laxenburg (Austria). It was made possible through the financial support of the European Commission Joint Research Center, and the German Federal Ministry for the Environment, Nature Conservation and Nuclear Safety (RESTORE+ project). Declarations of interest: none.

\section{References}

Adami, M., Rudorff, B.F.T., Freitas, R.M., Aguiar, D.A., Sugawara, L.M., Mello, M.P., 2012. Remote Sensing Time Series to Evaluate Direct Land Use Change of Recent Expanded Sugarcane Crop in Brazil. Sustainability 4.

Alexandratos, N., Bruinsma, J., 2012. World agriculture towards 2030/2050: the 2012 revision, ESA Working paper No. 12-03, Rome.

ANFAVEA, 2018. Carta da ANFAVEA [ANFAVEA letter], São Paulo, Brazil, p. 12.

ANP, 2017a. Série histórica do levantamento de preços e de margens de comercialização de combustíveis [Historical series of prices and fuel sales margins]. Agência Nacional do Petróleo, Gás Natural e Biocombustíveis.

ANP, 2017b. Vendas, pelas Distribuidoras, dos Derivados Combustíveis de Petróleo [Sales of fuels derived from oil by distributors]. Agência Nacional do Petróleo, Gás Natural e Biocombustíveis.

Bordonal, R.d.O., Carvalho, J.L.N., Lal, R., de Figueiredo, E.B., de Oliveira, B.G., La Scala, N., 2018. Sustainability of sugarcane production in Brazil. A review. Agronomy for Sustainable Development 38, 13.

Brasil, 2017. Law no. 13576/2017. Dispõe sobre a Política Nacional de Biocombustíveis (RenovaBio) e dá outras providências [Rules about the national biofuels policy (Renovabio) and other popositions]. Presidência da República, Brasil. 
Brazil, 2016. Intended Nationally Determined Contribution: towards achieving the objective of the United Nations Framework Convention on Climate Change.

CETESB, 2013. Curvas de intensidade de uso por tipo de veículo automotor da frota da cidade de São Paulo [Intensity of use curves per type of vehicle in the São Paulo city fleet], p. 68.

CETESB, 2017. Emissões veiculares no estado de são paulo 2016 [São Paulo state emissions of vehicles 2016], p. 221.

Cohn, A.S., Mosnier, A., Havlík, P., Valin, H., Herrero, M., Schmid, E., O’Hare, M. and Obersteiner, M., 2014. Cattle ranching intensification in Brazil can reduce global greenhouse gas emissions by sparing land from deforestation. Proceedings of the National Academy of Sciences, 111(20), pp.7236-7241.

COPPE/EPE, 2014. Descrição de trajetórias de oferta e uso final de energia no Brasil para o período 2013-2050 [Description of supply and final use of energy in Brazil for the 2013-2050 period], Rio de Janeiro, p. 19.

Danielsen, F., Beukema, H., Burgess, N.D., Parish, F., Brühl, C.A., Donald, P.F., Murdiyarso, D., Phalan, B., Reijnders, L., Struebig, M., Fitzherbert, E.B., 2009. Biofuel Plantations on Forested Lands: Double Jeopardy for Biodiversity and Climate. Conservation Biology 23, 348-358.

Dellink, R., Chateau, J., Lanzi, E., Magné, B., 2017. Long-term economic growth projections in the Shared Socioeconomic Pathways. Global Environmental Change 42, 200-214.

Dias, L.C.P., Pimenta, F.M., Santos, A.B., Costa, M.H., Ladle, R.J., 2016. Patterns of land use, extensification, and intensification of Brazilian agriculture. Global Change Biology 22, 28872903.

EPE, 2006. Balanço Energético Nacional 2006: Ano base 2005 [Brazilian Energy Balance 2006 Year 2005], Rio de Janeiro, p. 188.

EPE, 2016. Nota técnica DEA 13/15. Demanda de energia 2050 [Technical note DEA 13/15. Energy demand 2050], Estudos da demanda de energia. Ministério de Minas e Energia. Empresa de Pesquisa Energética, Rio de Janeiro, Brazil, p. 257.

EPE, 2018a. Balanço Energético Nacional 2018: Ano base 2017 [Brazilian Energy Balance 2018 Year 2017], Rio de Janeiro, p. 292.

EPE, 2019. Balanço Energético Nacional: séries históricas completas. Capítulo 3, consumo de energia por setor 1970 - 2018 [Brazilian Energy Balance: full historical series. Chapter 3, energy consumption by sector 1970 - 2018] Rio de Janeiro.

EPE, 2018b. Cenários de Oferta de Etanol e Demanda do Ciclo Otto 2018-2030 [Ethanol supply scenarios and Otto Cycle demand 2018-2030] Rio de Janeiro, p. 41. 
FAO, 2018. FAOSTAT database collections. Food and Agriculture Organization of the United Nations, Rome.

Fargione, J., Hill, J., Tilman, D., Polasky, S., Hawthorne, P., 2008. Land Clearing and the Biofuel Carbon Debt. Science 319, 1235-1238.

Ferreira Filho, J.B.d.S., Horridge, M., 2014. Ethanol expansion and indirect land use change in Brazil. Land Use Policy 36, 595-604.

Foley, J.A., DeFries, R., Asner, G.P., Barford, C., Bonan, G., Carpenter, S.R., Chapin, F.S., Coe, M.T., Daily, G.C., Gibbs, H.K., Helkowski, J.H., Holloway, T., Howard, E.A., Kucharik, C.J., Monfreda, C., Patz, J.A., Prentice, I.C., Ramankutty, N., Snyder, P.K., 2005. Global Consequences of Land Use. Science 309, 570-574.

GFEI, 2018. The Global Fuel Economy Initiative: delivering sustainable development goal 7. High-level political forum on sustainable development, p. 32.

Havlík, P., Schneider, U.A., Schmid, E., Böttcher, H., Fritz, S., Skalský, R., Aoki, K., Cara, S.D., Kindermann, G., Kraxner, F., Leduc, S., McCallum, I., Mosnier, A., Sauer, T., Obersteiner, M., 2011. Global land-use implications of first and second generation biofuel targets. Energy Policy 39, 5690-5702.

Havlík, P., Valin, H., Herrero, M., Obersteiner, M., Schmid, E., Rufino, M.C., Mosnier, A., Thornton, P.K., Böttcher, H., Conant, R.T., Frank, S., Fritz, S., Fuss, S., Kraxner, F., Notenbaert, A., 2014. Climate change mitigation through livestock system transitions. Proceedings of the National Academy of Sciences 111, 3709-3714.

Herrero, M., Havlík, P., Valin, H., Notenbaert, A., Rufino, M.C., Thornton, P.K., Blümmel, M., Weiss, F., Grace, D., Obersteiner, M., 2013. Biomass use, production, feed efficiencies, and greenhouse gas emissions from global livestock systems. Proceedings of the National Academy of Sciences 110, 20888-20893.

Herrero, M., Thornton, P.K., Kruska, R., Reid, R.S., 2008. Systems dynamics and the spatial distribution of methane emissions from African domestic ruminants to 2030. Agriculture, Ecosystems \& Environment 126, 122-137.

IPCC, 2014. Climate Change 2014: Mitigation of climate change. Contribution of working group III to the fifth assessment report of the Intergovernmental Panel on Climate Change [Edenhofer, O., R. Pichs-Madruga, Y. Sokona, E. Farahani, S. Kadner, K. Seyboth, A. Adler, I. Baum, S. Brunner, P. Eickemeier, B. Kriemann, J. Savolainen, S. Schlömer, C. von Stechow, T. Zwickel and J.C. Minx (eds.)]. Cambridge, United Kingdom and New York, NY, USA, p. 1454 . 
Koh, L.P., Ghazoul, J., 2008. Biofuels, biodiversity, and people: Understanding the conflicts and finding opportunities. Biological Conservation 141, 2450-2460.

Lapola, D.M., Schaldach, R., Alcamo, J., Bondeau, A., Koch, J., Koelking, C., Priess, J.A., Turner, B.L., 2010. Indirect Land-Use Changes Can Overcome Carbon Savings from Biofuels in Brazil. Proceedings of the National Academy of Sciences of the United States of America 107, 3388-3393.

Manzatto, C.V., Assad, E.D., Bacca, J.F.M., Zaroni, M.J., Pereira, S.E.M., 2009. Zoneamento Agroecológico da Cana-de-Açúcar: Expandir a produção, preservar a vida, garantir o futuro [Sugarcane Agroecological Zoning: expanding production, preserving life and guaranteeing the future], Documento 110 ed, Rio de Janeiro.

MAPA, 2017. Projeções do agronegócio: Brasil 2016/17 a 2026/27 projeções de longo prazo [Agribusiness projections: Brazil 2016/17 to 2026/27 long-term projections], p. 103.

Martha, G.B., Alves, E., Contini, E., 2012. Land-saving approaches and beef production growth in Brazil. Agricultural Systems 110, 173-177.

Melo, M.R.d.S., Rocha, J.V., Manabe, V.D., Lamparelli, R.A.C., 2018. Intensity of land use changes in a sugarcane expansion region, Brazil. Journal of Land Use Science 13, 182-197.

MMA, 2013. Inventário Nacional de Emissões Atmosféricas por Veículos Automotores Rodoviários 2013: Ano-base 2012 [National emissions inventory for road vehicles 2013: 2012 baseline], Brasília, p. 114.

MME, 2018. Proposta de metas compulsórias anuais de redução de emissões na comercialização de combustíveis. Consulta pública - Anexo da nota técnica 12/2018/DBIO/SPG [Proposal of annual compulsory targets for emission reduction in the commercialization of fuels. Public consultation - Annex to technical note 12/2018/DBIO/SPG], p. 30.

OECD, 2017. World Energy Outlook 2017. Paris: Organization for Economic Cooperation and Development.

OECD, 2018. Inland road passenger transport by passenger cars. Trends in the Transport Sector. The International Transport Forum. Database provider: OECD.Stat.

OECD, FAO, 2018. OECD-FAO Agricultural Outlook (Edition 2018).

O’Neill, B.C., Kriegler, E., Ebi, K.L., Kemp-Benedict, E., Riahi, K., Rothman, D.S., van Ruijven, B.J., van Vuuren, D.P., Birkmann, J., Kok, K. and Levy, M., 2017. The roads ahead: Narratives for shared socioeconomic pathways describing world futures in the 21 st century. Global Environmental Change, 42, pp.169-180.

Riahi, K., van Vuuren, D.P., Kriegler, E., Edmonds, J., O’Neill, B.C., Fujimori, S., Bauer, N., Calvin, K., Dellink, R., Fricko, O., Lutz, W., Popp, A., Cuaresma, J.C., Kc, S., Leimbach, M., 
Jiang, L., Kram, T., Rao, S., Emmerling, J., Ebi, K., Hasegawa, T., Havlik, P., Humpenöder, F., Da Silva, L.A., Smith, S., Stehfest, E., Bosetti, V., Eom, J., Gernaat, D., Masui, T., Rogelj, J., Strefler, J., Drouet, L., Krey, V., Luderer, G., Harmsen, M., Takahashi, K., Baumstark, L., Doelman, J.C., Kainuma, M., Klimont, Z., Marangoni, G., Lotze-Campen, H., Obersteiner, M., Tabeau, A., Tavoni, M., 2017. The Shared Socioeconomic Pathways and their energy, land use, and greenhouse gas emissions implications: An overview. Global Environmental Change 42, 153-168.

Rudorff, B.F.T., Aguiar, D.A., Silva, W.F., Sugawara, L.M., Adami, M., Moreira, M.A., 2010. Studies on the Rapid Expansion of Sugarcane for Ethanol Production in São Paulo State (Brazil) Using Landsat Data. Remote Sensing 2.

Searchinger, T., Heimlich, R., Houghton, R.A., Dong, F., Elobeid, A., Fabiosa, J., Tokgoz, S., Hayes, D., Yu, T.-H., 2008. Use of U.S. Croplands for Biofuels Increases Greenhouse Gases through Emissions from Land-Use Change. Science 319, 1238-1240.

Sindipeças, Abipeças, 2017. Relatório da frota circulante de 2017 [2017 fleet report], 04/2016 ed. Sindicato Nacional da Indústria de Componentes para Veículos Automotores e Associação Brasileira da Indústria de Autopeças, São Paulo, Brazil, p. 5.

Smith, K.A., Searchinger, T.D., 2012. Crop-based biofuels and associated environmental concerns. GCB Bioenergy 4, 479-484.

Soterroni, A.C., Mosnier, A., Carvalho, A.X.Y., Câmara, G., Obersteiner, M., Andrade, P.R., Souza, R.C., Brock, R., Pirker, J., Kraxner, F., Havlík, P., Kapos, V., Zu Ermgassen, E.K.H.J., Valin, H., Ramos, F.M., 2018. Future environmental and agricultural impacts of Brazil's Forest Code. Environmental Research Letters 13, 074021.

Soterroni, A.C., Ramos, F.M., Mosnier, A., Fargione, J., Andrade, P.R., Baumgarten, L., Pirker, J., Obersteiner, M., Kraxner, F., Câmara, G., Carvalho, A.X.Y., Polasky, S., 2019. Expanding the Soy Moratorium to Brazil's Cerrado. Science Advances Vol. 5, no 7, eaav7336.

Valin, H., Havlík, P., Forsell, N., Frank, S., Mosnier, A., Peters, D., Hamelinck, C., Spöttle, M., Berg, M.v.d., 2013. Description of the GLOBIOM (IIASA) model and comparison with the MIRAGE-BioF (IFPRI) model, EC project ENER/C1/428-2012 - LOT 2 Assessing the land use impact of EU biofuels policy.

Valin, H., Sands, R.D., van der Mensbrugghe, D., Nelson, G.C., Ahammad, H., Blanc, E., Bodirsky, B., Fujimori, S., Hasegawa, T., Havlik, P., Heyhoe, E., Kyle, P., Mason-D'Croz, D., Paltsev, S., Rolinski, S., Tabeau, A., van Meijl, H., von Lampe, M., Willenbockel, D., 2014. The future of food demand: understanding differences in global economic models. Agricultural Economics 45, 51-67. 
van der Hilst, F., Verstegen, J.A., Woltjer, G., Smeets, E.M.W., Faaij, A.P.C., 2018. Mapping land use changes resulting from biofuel production and the effect of mitigation measures. GCB Bioenergy 10, 804-824.

Verstegen, J.A., van der Hilst, F., Woltjer, G., Karssenberg, D., de Jong, S.M. and Faaij, A.P., 2016. What can and can't we say about indirect land-use change in Brazil using an integrated economic-land-use change model?. Gcb Bioenergy, 8(3), pp.561-578.

Wicke, B., Van Der Hilst, F., Daioglou, V., Banse, M., Beringer, T., Gerssen-Gondelach, S., Heijnen, S., Karssenberg, D., Laborde, D., Lippe, M. and Van Meijl, H., 2015. Model collaboration for the improved assessment of biomass supply, demand, and impacts. Gcb Bioenergy, 7(3), pp.422-437.

Williams, J.R., 1995. The EPIC model, in: Computer models in watershed hydrology, edited by: Singh, V. P. Water Resources Publications, Highlands Ranch.

World Bank, 2017. World Bank national accounts data and OECD National Accounts data files. The World Bank, Data Bank.

Zalles, V., Hansen, M.C., Potapov, P.V., Stehman, S.V., Tyukavina, A., Pickens, A., Song, X.-P., Adusei, B., Okpa, C., Aguilar, R., John, N., Chavez, S., 2019. Near doubling of Brazil's intensive row crop area since 2000. Proceedings of the National Academy of Sciences 116, 428. 


\section{Supporting Information}

\section{Validation}

In this section we compare GLOBIOM-Brazil projections for 2010 to official statistics from Brazilian government. Accumulated deforestation in the Amazon biome between 2000 and 2010 according to GLOBIOM-Brazil simulations in this study are 16.4 million hectares (Mha), whereas PRODES/INPE Amazon deforestation map indicates 16.5 Mha of deforested area during the same period. For total cropland area and production, we use data on harvested areas from the Municipal Crop Production survey (IBGE, 2017b) and highlight the four most extensive crops in Brazil by 2010 according to GLOBIOM-Brazil simulations (i.e. soybeans, corn, sugarcane, and dry beans). The comparison to GLOBIOM-Brazil outputs is presented in figures SI2 and SI3. Since sugarcane is the main crop of interest within the scope of this study, particularly for its cropland area and production we are also reporting data from National Supply Company, Ministry of Agriculture (CONAB, 2010) because they better reflect the sugarcane crop year in Brazil that extends from April until March of the following year. Outputs from GLOBIOM-Brazil for 2010 livestock numbers are compared to data from the Municipal Livestock Production Survey (IBGE, 2017a) and presented in figure SI4.

Table S1. Historical data of fleet numbers in Brazil, per type of vehicle. Numbers for each type of vehicle include passenger and commercial cars.

\begin{tabular}{rlllllrr} 
& $\begin{array}{l}\text { Total light } \\
\text { vehicles }\end{array}$ & $\begin{array}{l}\text { Ethanol- } \\
\text { only cars }\end{array}$ & \multicolumn{1}{l}{$\begin{array}{l}\text { Flex-fuel } \\
\text { cars }\end{array}$} & $\begin{array}{l}\text { Gasoline- } \\
\text { only cars }\end{array}$ & \multicolumn{1}{l}{$\begin{array}{l}\text { Diesel } \\
\text { cars }\end{array}$} & $\begin{array}{l}\text { Flex } \\
\text { motorcycles }\end{array}$ & $\begin{array}{l}\text { Gasoline-only } \\
\text { motorcycles }\end{array}$ \\
\hline 2006 & $28,514,908$ & $2,078,075$ & $2,605,227$ & 16.219 .735 & 920.375 & 0 & 6.691 .496 \\
2007 & $31,003,231$ & $1,887,331$ & $4,590,150$ & $15,714,084$ & 969,544 & 0 & $7,842,122$ \\
2008 & $33,978,312$ & $1,709,203$ & $6,886,280$ & $15,139,184$ & $1,048,609$ & 0 & $9,195,036$ \\
2009 & $36,852,168$ & $1,543,750$ & $9,482,403$ & $14,534,532$ & $1,134,423$ & 183,375 & $9,973,685$ \\
2010 & $40,166,457$ & $1,390,778$ & $12,268,798$ & $13,961,749$ & $1,254,140$ & 509,376 & $10,781,616$ \\
2011 & $43,667,739$ & $1,249,951$ & $14,981,568$ & $13,466,154$ & $1,398,200$ & $1,414,660$ & $11,157,206$ \\
2012 & $46,804,623$ & $1,120,795$ & $17,948,371$ & $12,858,143$ & $1,533,936$ & $2,097,165$ & $11,246,213$
\end{tabular}




$\begin{array}{llllllll}2013 & 49,955,938 & 908,821 & 20,822,062 & 12,543,402 & 1,636,612 & 2,172,550 & 11,872,492 \\ 2014 & 51,903,554 & 744,142 & 22,991,514 & 11,964,416 & 1,714,905 & 2,621,660 & 11,866,916 \\ 2015 & 53,210,405 & 610,377 & 24,831,076 & 11,338,629 & 1,758,297 & 3,102,897 & 11,569,129 \\ 2016 & 53,441,552 & 460,848 & 26,132,596 & 10,587,671 & 1,770,070 & 3,359,335 & 11,131,032\end{array}$

Source: Data reconstructed based on MMA (2013), Sindipeças and Abipeças (2017) and CETESB (2017).

Because the National Emissions Inventory for Road Vehicles presents fleet numbers up to 2012, we extrapolated data between 2013 and 2016 based on Sindipeças and Abipeças (2017) and CETESB (2017).

Table S2. Increase rates for fleet numbers, in relation to the previous year, per type of vehicle between 2013 and 2016.

\begin{tabular}{rrrrrrr} 
& $\begin{array}{l}\text { Ethanol- } \\
\text { only cars }\end{array}$ & \multicolumn{2}{l}{$\begin{array}{l}\text { Flex-fuel } \\
\text { cars }\end{array}$} & \multicolumn{2}{l}{$\begin{array}{l}\text { Gasoline- } \\
\text { only cars }\end{array}$} & \multicolumn{2}{l}{$\begin{array}{l}\text { Diesel } \\
\text { cars }\end{array}$} & \multicolumn{2}{l}{$\begin{array}{l}\text { Total } \\
\text { motorcycles }\end{array}$} & $\begin{array}{l}\text { Flex-fuel } \\
\text { motorcycles }\end{array}$ \\
\hline 2013 & 0.81 & 1.16 & 0.98 & 1.07 & 1.05 & 1.04 \\
2014 & 0.82 & 1.10 & 0.95 & 1.05 & 1.03 & 1.21 \\
2015 & 0.82 & 1.08 & 0.95 & 1.03 & 1.01 & 1.18 \\
2016 & 0.76 & 1.05 & 0.93 & 1.01 & 0.99 & 1.08
\end{tabular}

Source: Data reconstructed based on Sindipeças and Abipeças (2017) and CETESB (2017).

Table S3. Summary statistics log-log data panel analysis. United States is the country of reference in the model, having no fixed effect term.

\begin{tabular}{r|rrrr} 
& Estimate & Std. error & $\mathrm{t}$ value & $\mathrm{p}$ value \\
\hline (Intercept $)$ & 1.102 & 0.166 & 6.66 & 0.000 \\
$\log ($ Gdpcap $)$ & 0.802 & 0.015 & 51.95 & 0.000 \\
Albania & 0.080 & 0.054 & 1.47 & 0.142 \\
Armenia & -0.848 & 0.056 & -15.15 & 0.000 \\
Australia & -0.244 & 0.028 & -8.73 & 0.000 \\
Belgium & -0.455 & 0.028 & -16.21 & 0.000 \\
Brazil & -0.062 & 0.122 & -0.50 & 0.614 \\
Bulgaria & -1.557 & 0.053 & -29.53 & 0.000 \\
China & -0.922 & 0.055 & -16.76 & 0.000 \\
Czech Republic & -0.183 & 0.035 & -5.18 & 0.000 \\
Denmark & -0.562 & 0.029 & -19.17 & 0.000 \\
Finland & -0.304 & 0.028 & -10.87 & 0.000 \\
France & -0.270 & 0.028 & -9.65 & 0.000
\end{tabular}




\begin{tabular}{r|rrrr} 
Germany & -0.440 & 0.028 & -15.70 & 0.000 \\
Hungary & -0.106 & 0.038 & -2.83 & 0.005 \\
Iceland & -0.023 & 0.031 & -0.74 & 0.458 \\
Italy & -0.304 & 0.028 & -10.76 & 0.000 \\
Korea & -0.704 & 0.039 & -18.00 & 0.000 \\
Macedonia & -0.013 & 0.051 & -0.25 & 0.804 \\
Norway & -0.834 & 0.029 & -29.20 & 0.000 \\
Poland & -0.215 & 0.040 & -5.44 & 0.000 \\
Slovak Republic & -0.304 & 0.037 & -8.18 & 0.000 \\
Spain & -0.693 & 0.029 & -23.57 & 0.000 \\
Sweden & -0.341 & 0.028 & -12.27 & 0.000 \\
Switzerland & -0.735 & 0.030 & -24.38 & 0.000 \\
United Kingdom & -0.270 & 0.028 & -9.49 & 0.000
\end{tabular}

Table S4. Average age of vehicles in the state of São Paulo, Brazil.

\begin{tabular}{|c|c|c|c|c|c|c|}
\hline & $\begin{array}{l}\text { Ethanol- } \\
\text { only cars }\end{array}$ & $\begin{array}{l}\text { Flex-fuel } \\
\text { cars }\end{array}$ & $\begin{array}{l}\text { Gasoline- } \\
\text { only cars }\end{array}$ & $\begin{array}{l}\text { Diesel } \\
\text { cars }\end{array}$ & $\begin{array}{l}\text { Flex } \\
\text { motorcycles }\end{array}$ & $\begin{array}{l}\text { Gasoline-only } \\
\text { motorcycles }\end{array}$ \\
\hline 2006 & 17.8 & 1.6 & 9.6 & 9.4 & 0 & 5.1 \\
\hline 2007 & 18.6 & 1.9 & 10.2 & 9.4 & 0 & 4.9 \\
\hline 2008 & 19.4 & 2.3 & 11.0 & 9.0 & 0 & 5.0 \\
\hline 2009 & 20.2 & 2.7 & 11.7 & 8.8 & 0 & 5.3 \\
\hline 2010 & 21.0 & 3.1 & 12.4 & 8.3 & 1.0 & 5.9 \\
\hline 2011 & 21.8 & 3.5 & 13.0 & 7.9 & 1.5 & 6.3 \\
\hline 2012 & 22.6 & 4.0 & 13.6 & 7.7 & 2.0 & 6.8 \\
\hline 2013 & 23.4 & 4.4 & 14.3 & 7.5 & 2.2 & 7.3 \\
\hline 2014 & 24.3 & 4.9 & 15.0 & 7.5 & 2.7 & 7.9 \\
\hline 2015 & 25.1 & 5.5 & 15.5 & 7.9 & 3.2 & 8.5 \\
\hline 2016 & 26.0 & 6.1 & 16.2 & 8.3 & 3.8 & 9.2 \\
\hline
\end{tabular}

Source: CETESB (2017).

Table S5. Parameters applied to the intensity of use curves for each type of vehicle.

\begin{tabular}{lrrrr} 
& $\alpha$ & $\beta$ & $\gamma$ & $\delta$ \\
\hline Gasoline-only cars & 0.67 & -49.57 & 779.66 & 11266 \\
Ethanol-only cars & -3.29 & 174.31 & -3083.60 & 31628 \\
Flex-fuel cars & -24.29 & 426.19 & -2360.40 & 19178 \\
Diesel cars & 10.40 & 86.40 & -1271.30 & 29638 \\
Motorcycles & 1.34 & -60.49 & 442.92 & 12423
\end{tabular}

Source: CETESB (2013). 
Table S6. Calculated values of historical passenger transport demand per type of LDV, in millions.

\begin{tabular}{|c|c|c|c|c|c|c|}
\hline & $\begin{array}{l}\text { Ethanol- } \\
\text { only cars }\end{array}$ & $\begin{array}{l}\text { Flex-fuel } \\
\text { cars }\end{array}$ & $\begin{array}{l}\text { Gasoline- } \\
\text { only cars }\end{array}$ & $\begin{array}{l}\text { Diesel } \\
\text { cars }\end{array}$ & $\begin{array}{l}\text { Flex } \\
\text { motorcycles }\end{array}$ & $\begin{array}{l}\text { Gasoline-only } \\
\text { motorcycles }\end{array}$ \\
\hline 2006 & 41,776 & 64,061 & 359,517 & 23,034 & 0 & 88,904 \\
\hline 2007 & 37,918 & 110,612 & 348,249 & 24,265 & 0 & 104,288 \\
\hline 2008 & 34,287 & 162,256 & 334,697 & 27,705 & 0 & 122,227 \\
\hline 2009 & 30,869 & 219,524 & 320,019 & 30,722 & 2,278 & 132,357 \\
\hline 2010 & 27,654 & 280,334 & 305,616 & 35,916 & 6,523 & 142,377 \\
\hline 2011 & 24,634 & 339,244 & 292,898 & 41,652 & 18,328 & 146,687 \\
\hline 2012 & 21,804 & 403,865 & 277,563 & 46,534 & 27,426 & 146,862 \\
\hline 2013 & 17,363 & 467,695 & 267,989 & 50,513 & 28,501 & 153,792 \\
\hline 2014 & 13,828 & 516,875 & 252,602 & 52,929 & 34,617 & 151,980 \\
\hline 2015 & 10,977 & 560,455 & 237,149 & 52,379 & 41,159 & 146,230 \\
\hline 2016 & 7,900 & 592,890 & 218,271 & 50,692 & 44,700 & 138,255 \\
\hline
\end{tabular}

Table S7. Historical percentage of each type of light-duty vehicle contributing to the total passenger transport demand.

\begin{tabular}{rrrrrrr} 
& $\begin{array}{l}\text { Ethanol- } \\
\text { only cars }\end{array}$ & \multicolumn{1}{l}{$\begin{array}{l}\text { Flex-fuel } \\
\text { cars }\end{array}$} & $\begin{array}{l}\text { Gasoline- } \\
\text { only cars }\end{array}$ & \multicolumn{1}{l}{$\begin{array}{l}\text { Diesel } \\
\text { cars }\end{array}$} & $\begin{array}{l}\text { Flex } \\
\text { motorcycles }\end{array}$ & $\begin{array}{l}\text { Gasoline-only } \\
\text { motorcycles }\end{array}$ \\
\hline 2006 & $7.24 \%$ & $11.10 \%$ & $62.28 \%$ & $3.99 \%$ & $0.00 \%$ & $15.40 \%$ \\
2007 & $6.06 \%$ & $17.69 \%$ & $55.69 \%$ & $3.88 \%$ & $0.00 \%$ & $16.68 \%$ \\
2008 & $5.03 \%$ & $23.82 \%$ & $49.14 \%$ & $4.07 \%$ & $0.00 \%$ & $17.94 \%$ \\
2009 & $4.20 \%$ & $29.84 \%$ & $43.49 \%$ & $4.18 \%$ & $0.31 \%$ & $17.99 \%$ \\
2010 & $3.46 \%$ & $35.11 \%$ & $38.28 \%$ & $4.50 \%$ & $0.82 \%$ & $17.83 \%$ \\
2011 & $2.85 \%$ & $39.29 \%$ & $33.92 \%$ & $4.82 \%$ & $2.12 \%$ & $16.99 \%$ \\
2012 & $2.36 \%$ & $43.71 \%$ & $30.04 \%$ & $5.04 \%$ & $2.97 \%$ & $15.89 \%$ \\
2013 & $1.76 \%$ & $47.44 \%$ & $27.18 \%$ & $5.12 \%$ & $2.89 \%$ & $15.60 \%$ \\
2014 & $1.35 \%$ & $50.53 \%$ & $24.70 \%$ & $5.17 \%$ & $3.38 \%$ & $14.86 \%$ \\
2015 & $1.05 \%$ & $53.46 \%$ & $22.62 \%$ & $5.00 \%$ & $3.93 \%$ & $13.95 \%$ \\
2016 & $0.75 \%$ & $56.32 \%$ & $20.73 \%$ & $4.82 \%$ & $4.25 \%$ & $13.13 \%$
\end{tabular}

Table S8. Total production, exports and non-energy ethanol consumption in the last 10 years, in billion litres.

\begin{tabular}{lrrrrrrrrrrr} 
& 2008 & 2009 & 2010 & 2011 & 2012 & 2013 & 2014 & 2015 & 2016 & 2017 & Average \\
\hline Total & 27.1 & 26.1 & 27.9 & 22.9 & 23.5 & 27.6 & 28.5 & 30.3 & 28.3 & 27.7 & 27.0 \\
Exports & 5.1 & 3.3 & 1.9 & 2.0 & 3.1 & 2.9 & 1.5 & 2.1 & 1.8 & 1.4 & 2.5 \\
Non- & 1.5 & 1.5 & 1.1 & 1.1 & 1.2 & 1.3 & 1.1 & 1.0 & 0.9 & 1.0 & 1.2 \\
energy & & & & & & & & & & &
\end{tabular}

Source: EPE (2006) and EPE (2018). 
Table S9. Final ethanol demand fed into GLOBIOM-Brazil for the Fossil fuel oriented scenario (FFO).

\begin{tabular}{cccccc} 
Hydrous ethanol & $\begin{array}{c}\text { Anhydrous } \\
\left(10_{3} \text { toe }\right)\end{array}$ & $\begin{array}{c}\text { Total ethanol } \\
\text { ethanol }\left(10_{3} \text { toe }\right)\end{array}$ & $\begin{array}{c}\text { Total ethanol } \\
\left(10_{12} \text { joules }\right)\end{array}$ & $\begin{array}{c}\text { Feedstock use } \\
\left(10_{3} \text { tonne }\right)\end{array}$ \\
\hline 2000 & $2,576.9$ & $3,024.2$ & 10.7 & $234,504.5$ & $137,254.9$ \\
2005 & $3,991.7$ & $4,382.5$ & 16.0 & $350,610.7$ & $205,211.5$ \\
2010 & $9,972.7$ & $4,462.0$ & 27.9 & $604,353.0$ & $353,726.3$ \\
2015 & $9,523.2$ & $6,174.8$ & 30.3 & $657,245.0$ & $384,683.8$ \\
2020 & $9,723.8$ & $7,803.3$ & 33.7 & $733,826.6$ & $429,506.8$ \\
2025 & $11,069.2$ & $7,484.4$ & 35.7 & $776,801.4$ & $454,659.9$ \\
2030 & $12,089.8$ & $7,323.2$ & 37.4 & $812,786.0$ & $475,721.6$
\end{tabular}

Table S10. Final ethanol demand fed into GLOBIOM-Brazil for the Business as usual scenario $(B A U)$.

\begin{tabular}{cccccc} 
Hydrous ethanol & $\begin{array}{c}\text { Anhydrous } \\
\left(10_{3} \text { toe }\right)\end{array}$ & $\begin{array}{c}\text { Total ethanol } \\
\text { ethanol }\left(10_{3} \text { toe }\right)\end{array}$ & $\begin{array}{c}\text { Total ethanol } \\
\left(10_{12} \text { joules }\right)\end{array}$ & $\begin{array}{c}\text { Feedstock use } \\
\left(10_{3} \text { tonne }\right)\end{array}$ \\
\hline 2000 & $2,576.9$ & $3,024.2$ & 10.7 & $234,504.5$ & $137,254.9$ \\
2005 & $3,991.7$ & $4,382.5$ & 16.0 & $350,610.7$ & $205,211.5$ \\
2010 & $9,972.7$ & $4,462.0$ & 27.9 & $604,353.0$ & $353,726.3$ \\
2015 & $9,523.2$ & $6,174.8$ & 30.3 & $657,245.0$ & $384,683.8$ \\
2020 & $12,221.6$ & $7,417.6$ & 37.9 & $822,253.0$ & $481,262.6$ \\
2025 & $15,933.0$ & $7,456.7$ & 45.2 & $979,278.8$ & $573,169.4$ \\
2030 & $18,230.3$ & $7,715.0$ & 50.2 & $1,086,277.2$ & $635,795.3$
\end{tabular}

Table S11. Final ethanol demand fed into GLOBIOM-Brazil for the Renewable fuels oriented scenario $(R F O)$.

\begin{tabular}{llllll} 
& $\begin{array}{c}\text { Hydrous ethanol } \\
\left(10_{3} \text { toe }\right)\end{array}$ & $\begin{array}{c}\text { Anhydrous } \\
\text { ethanol }\left(10_{3} \text { toe }\right)\end{array}$ & $\begin{array}{c}\text { Total ethanol } \\
\left(10_{9} \text { litres }\right)\end{array}$ & $\begin{array}{c}\text { Total ethanol } \\
\left(10_{12} \text { joules }\right)\end{array}$ & $\begin{array}{c}\text { Feedstock use } \\
\left(10_{3} \text { tonne }\right)\end{array}$ \\
\hline 2000 & $2,576.9$ & $3,013.5$ & 10.7 & $234,057.4$ & $136,993.2$ \\
2005 & $3,991.7$ & $4,382.5$ & 16.0 & $350,610.7$ & $205,211.5$ \\
2010 & $9,972.7$ & $4,462.0$ & 27.9 & $604,353.0$ & $353,726.3$
\end{tabular}




$\begin{array}{llllll}2015 & 9,523.2 & 6,174.8 & 30.3 & 657,245.0 & 384,683.8 \\ 2020 & 17,904.4 & 6,522.3 & 47.3 & 1,022,696.9 & 598,581.9 \\ 2025 & 25,277.2 & 5,821.7 & 60.5 & 1,302,048.6 & 762,085.7 \\ 2030 & 30,904.2 & 5,369.4 & 70.7 & 1,518,705.1 & 888,894.2\end{array}$

Table S12. Detailed evolution of the land-use classes between 2010 and 2030 by Brazilian biomes. Values are presented in million hectares (Mha).

\begin{tabular}{|c|c|c|c|c|}
\hline & \multicolumn{2}{|c|}{ BAU-FFO } & \multicolumn{2}{|c|}{ RFO-FFO } \\
\hline & 2020 & 2030 & 2020 & 2030 \\
\hline Sugarcane & 0.44 & 1.44 & 1.56 & 3.77 \\
\hline Amazon & 0.00 & 0.01 & 0.00 & 0.01 \\
\hline Cerrado & 0.41 & 1.01 & 1.26 & 2.32 \\
\hline Atlantic forest & 0.02 & 0.43 & 0.29 & 1.44 \\
\hline Other crops & -0.04 & -0.01 & -0.10 & -0.15 \\
\hline Amazon & -0.03 & 0.00 & -0.04 & -0.07 \\
\hline Cerrado & -0.03 & -0.09 & -0.08 & -0.14 \\
\hline Atlantic forest & 0.01 & 0.00 & 0.02 & -0.03 \\
\hline Native vegetation & $\mathbf{0 . 0 0}$ & -0.10 & -0.02 & -0.18 \\
\hline Amazon & 0.01 & -0.01 & 0.01 & -0.03 \\
\hline Cerrado & -0.01 & -0.08 & -0.02 & -0.13 \\
\hline Atlantic forest & 0.00 & 0.00 & 0.00 & 0.00 \\
\hline Non-productive landa & -0.09 & -0.11 & -0.60 & -0.71 \\
\hline Amazon & 0.01 & -0.02 & 0.01 & -0.03 \\
\hline Cerrado & -0.02 & -0.02 & -0.46 & -0.52 \\
\hline Atlantic forest & -0.02 & 0.01 & -0.19 & -0.14 \\
\hline Pastureland & -0.31 & -1.20 & -0.84 & -2.70 \\
\hline Amazon & 0.02 & 0.02 & 0.02 & 0.13 \\
\hline Cerrado & -0.31 & -0.77 & -0.65 & -0.49 \\
\hline Atlantic forest & -0.01 & -0.46 & -0.22 & -1.38 \\
\hline
\end{tabular}

aMosaics of natural vegetation and areas converted from agriculture but not currently under production.

Table S13. Ethanol demand projections for the LDV passenger transport sector in Brazil towards 2050.

\begin{tabular}{lccc} 
& FFO / SSP3 & BAU / SSP2 & RFO / SSP1 \\
\hline 2020 & 30.04 & 34.22 & 43.69 \\
2025 & 32.08 & 41.57 & 56.84 \\
2030 & 33.78 & 46.56 & 67.04 \\
2035 & 36.48 & 50.00 & 71.58 \\
2040 & 37.81 & 51.54 & 74.23 \\
2045 & 35.33 & 49.32 & 74.04
\end{tabular}



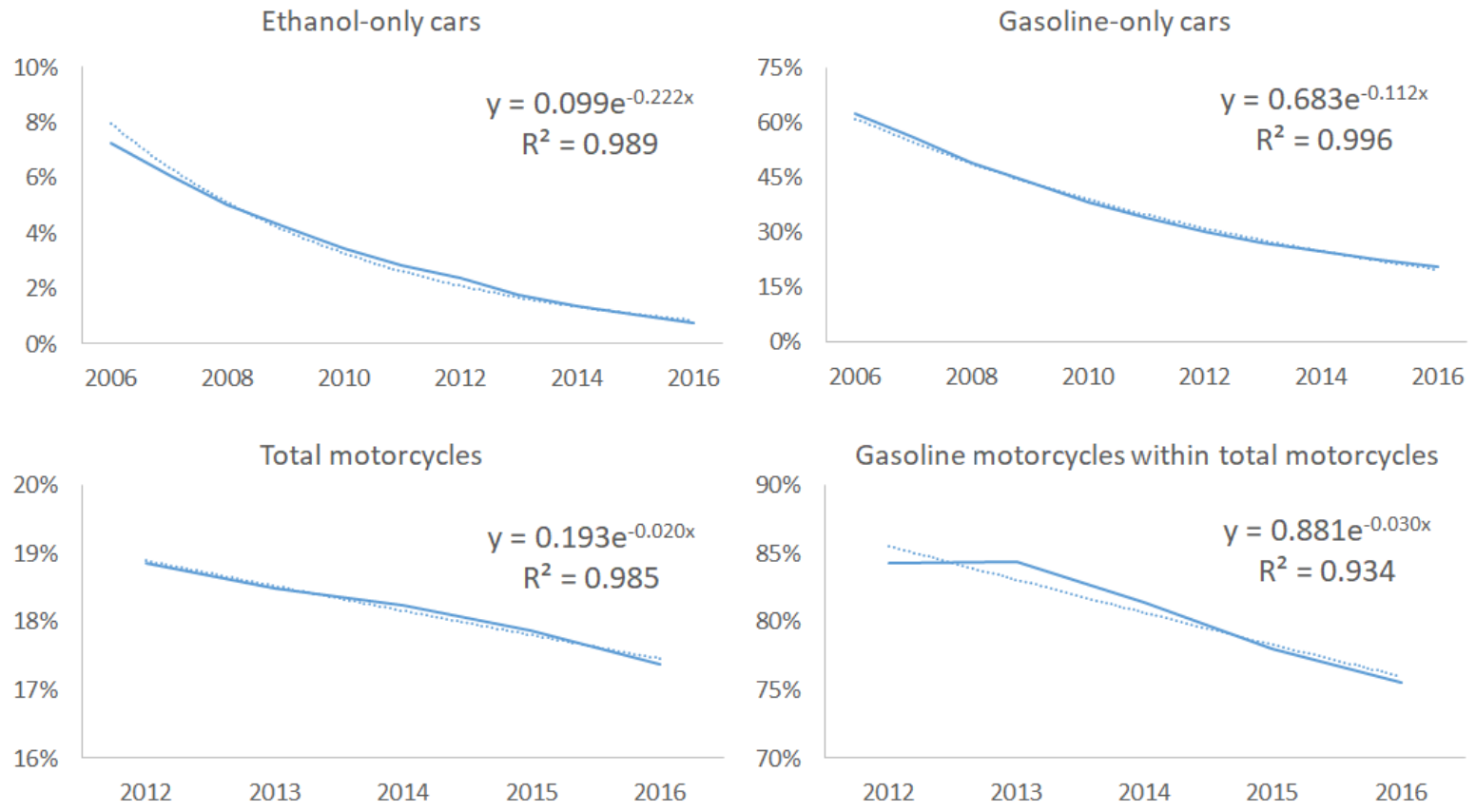

Figure S1. Trend curves of LDV's contribution on meeting passenger transport demand in Brazil. 


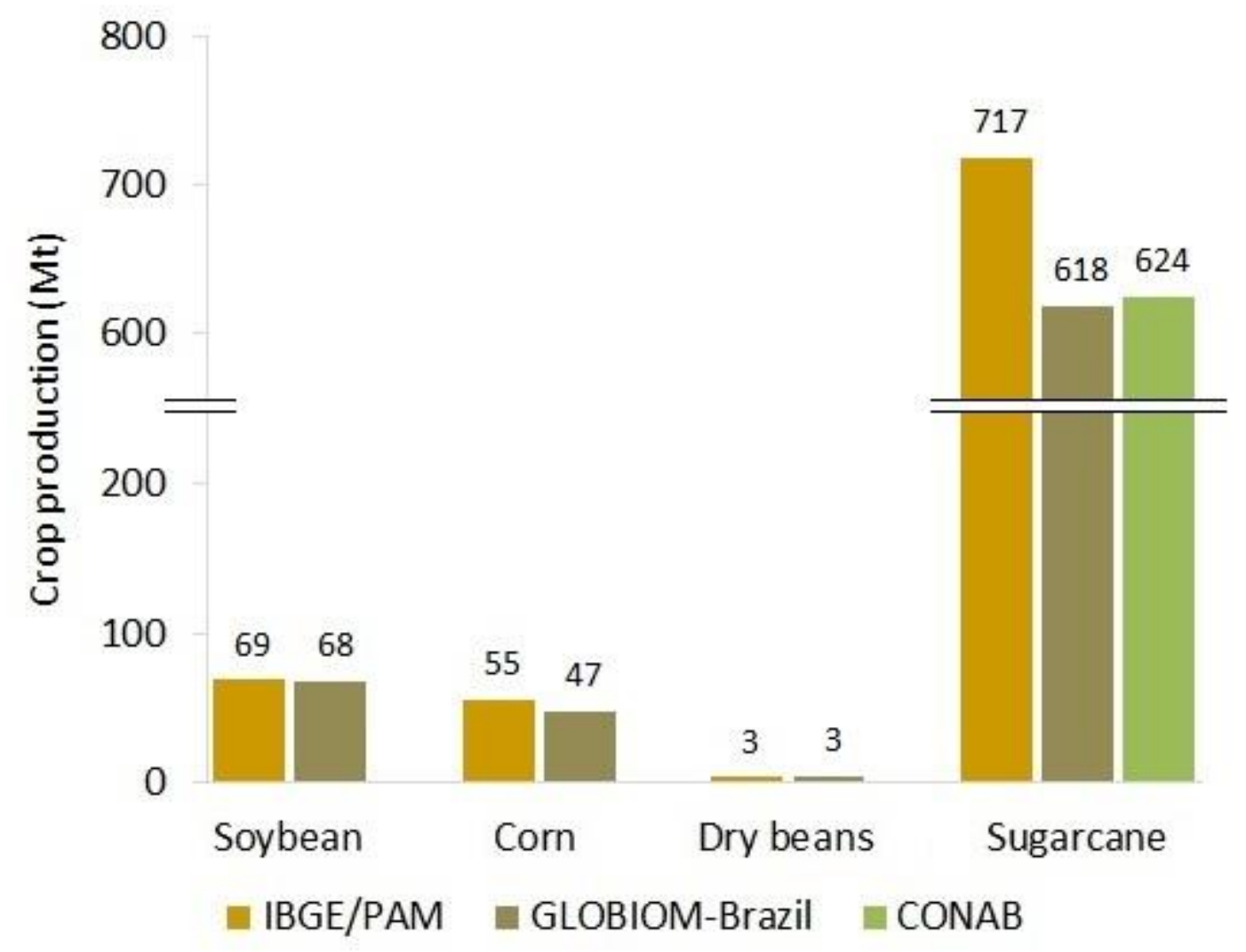

Figure S2. Crop production comparison per crop type between GLOBIOM-Brazil projections and IBGE/PAM for the year 2010 at national level. CONAB (2010) data is also included for sugarcane production comparison. $1 \mathrm{Mt}=106$ tonne. 


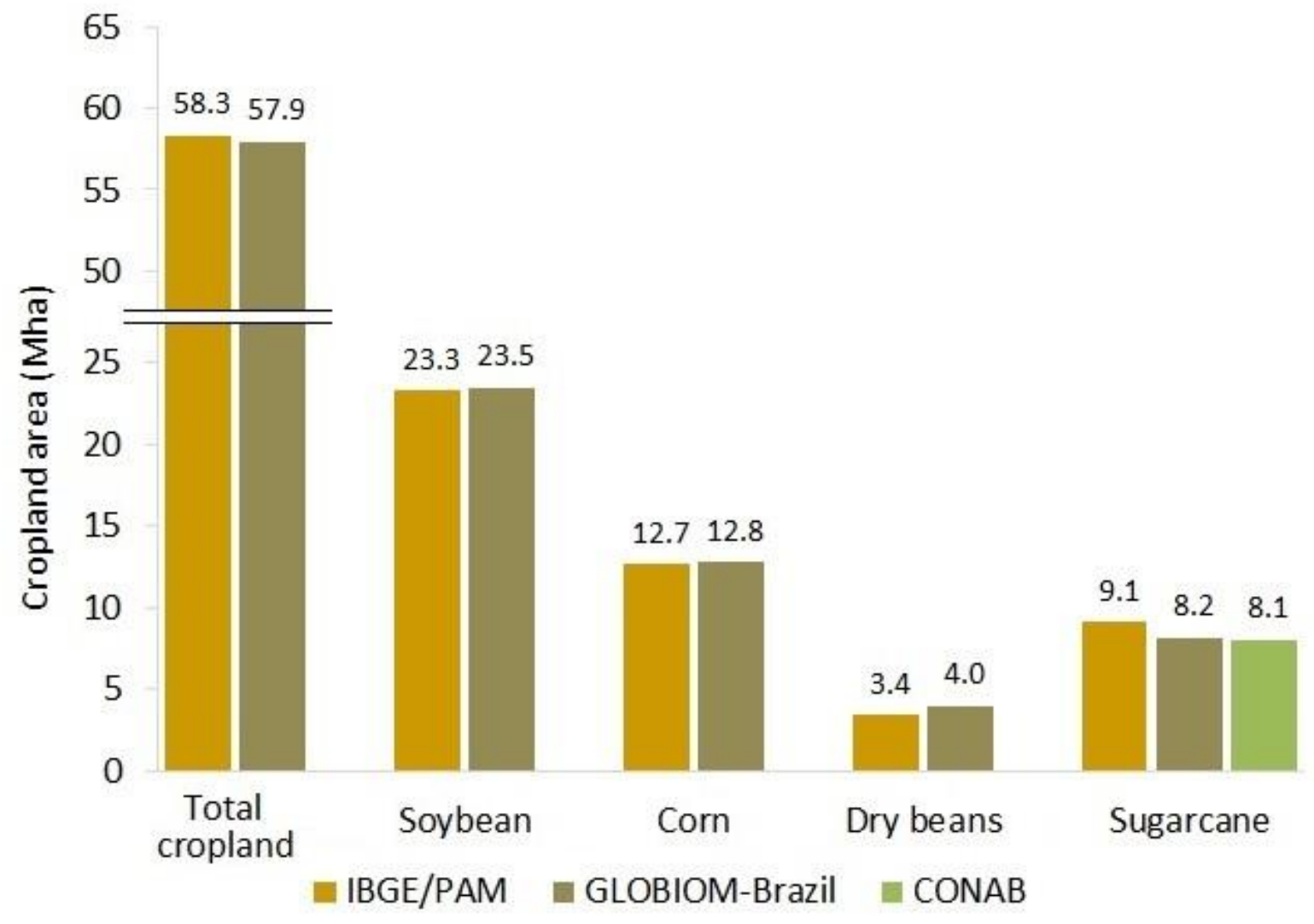

Figure S3. Cropland area comparison per crop type between GLOBIOM-Brazil projections and IBGE/PAM for the year 2010 at national level, along with the comparison to total cropland area. CONAB (2010) data is also included for sugarcane cropland area comparison. 1 Mha $=$ $104 \mathrm{~km} 4$. 


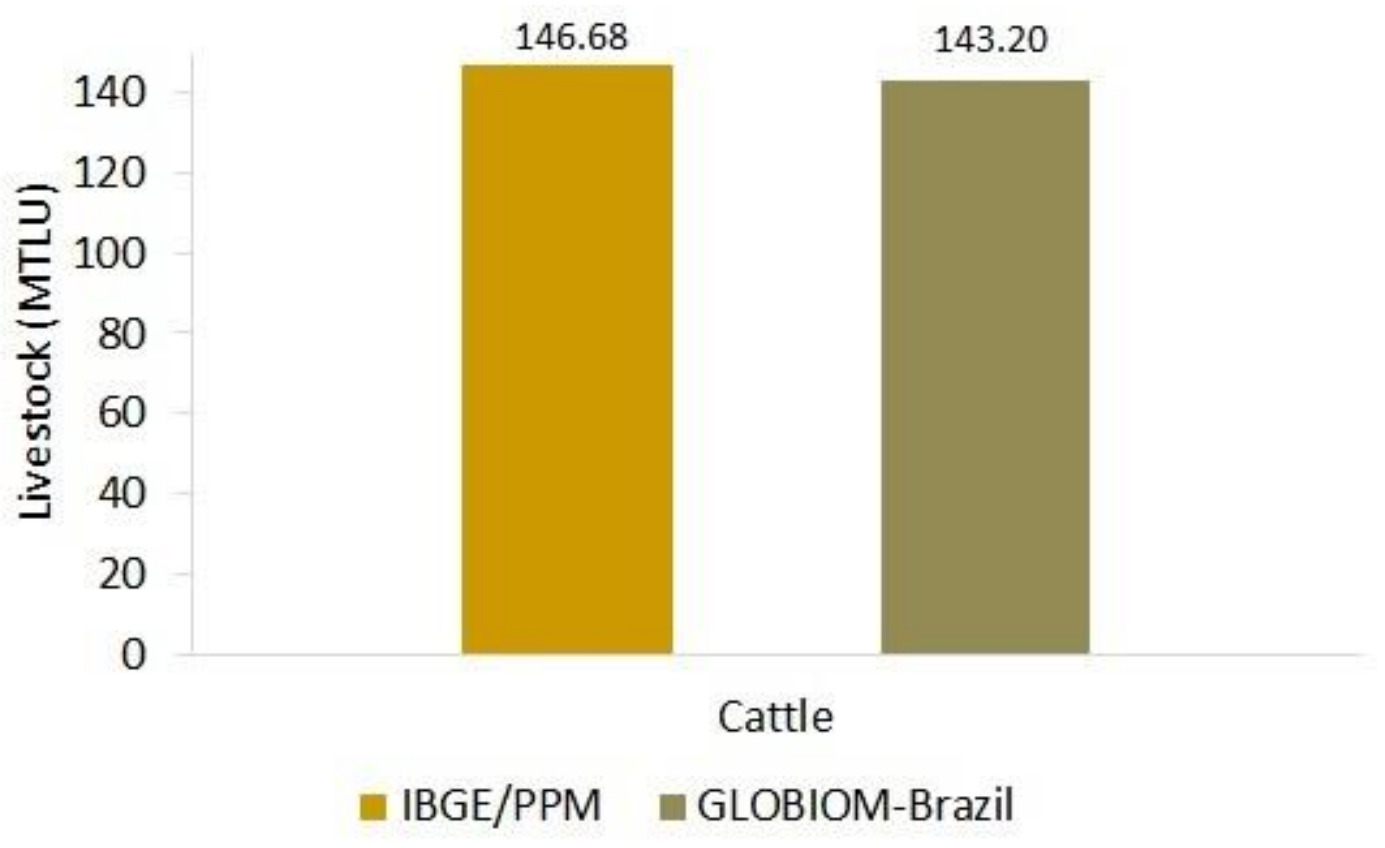

Figure S4. Cattle numbers comparison between GLOBIOM-Brazil projections and IBGE/PPM for the year 2010. Values are expressed in million tropical livestock units (MTLU). 1 TLU = 0.7 cattle.

References

CETESB, 2013. Curvas de intensidade de uso por tipo de veículo automotor da frota da cidade de São Paulo [Intensity of use curves per type of vehicle in the São Paulo city fleet], p. 68.

CETESB, 2017. Emissões veiculares no estado de são paulo 2016 [São Paulo state emissions of vehicles 2016], p. 221.

CONAB, 2010. Série histórica das safras: cana-de-açúcar - agrícola [Historical crop database: sugarcane - agricultural data]. Companhia Nacional de Abastecimento, Companhia Nacional de Abastecimento.

EPE, 2006. Balanço Energético Nacional 2006: Ano base 2005 [Brazilian Energy Balance 2006 Year 2005], Rio de Janeiro, p. 188.

EPE, 2018. Balanço Energético Nacional 2018: Ano base 2017 [Brazilian Energy Balance 2018 Year 2017], Rio de Janeiro, p. 292. 
IBGE, 2017a. Pesquisa da Pecuária Municipal (PPM) [Municipal livestock production survey (PPM)]. Instituto Brasileiro de Geografia e Estatística.

IBGE, 2017b. Produção Agrícola Municipal (PAM). Série histórica das culturas temporárias e permanentes 1974-2016 [Municipal Crop Production (PAM). Historical series of temporary and permanent crops 1974-2016]. Instituto Brasileiro de Geografia e Estatística.

MMA, 2013. Inventário Nacional de Emissões Atmosféricas por Veículos Automotores Rodoviários 2013: Ano-base 2012 [National emissions inventory for road vehicles 2013: 2012 baseline], Brasília, p. 114.

Sindipeças, Abipeças, 2017. Relatório da frota circulante de 2017 [2017 fleet report], 04/2016 ed. Sindicato Nacional da Indústria de Componentes para Veículos Automotores e Associação Brasileira da Indústria de Autopeças, São Paulo, Brazil, p. 5. 